Check for updates

Cite this: RSC Adv., 2020, 10, 16366

Received 18th February 2020

Accepted 16th April 2020

DOI: $10.1039 /$ dOra01569e

rsc.li/rsc-advances

\section{Palladium-catalyzed highly regioselective mono and double Sonogashira cross-coupling reactions of 5-substituted-1,2,3-triiodobenzene under ambient conditions $\uparrow$}

\author{
Raed M. Al-Zoubi, (DD *a Mothana K. Al-Omari, (D) ${ }^{\text {a }}$ Walid K. Al-Jammal (iD ${ }^{\text {a }}$ \\ and Michael J. Ferguson (D)
}

An efficient synthesis of 2,3-diiodinated diphenylacetylene and iodinated meta-terphenylacetylene derivatives through highly regioselective mono and double Sonogashira cross-coupling reactions of 5substituted-1,2,3-triiodobenzene is reported. Significantly, the regioselectivity of coupling reactions is exclusively performed at the terminal $\mathrm{C}-\mathrm{I}$ bonds, the less sterically hindered and the most regioactive positions. The highest isolated yields were achieved from reactions of electron-poor/neutral 1,2,3triiodoarene and electron-rich arylacetylene derivatives. The use of 2.0 equiv. of arylacetylenes in onepot fashion afforded the iodinated meta-terphenylacetylenes in excellent site selectivity and in good isolated yields. Different functional groups were found to be suitable under optimized conditions. This report discloses the first method to synthesize hitherto unknown 2,3-diiodinated diphenylacetylenes and iodinated meta-terphenylacetylenes that is facile, highly regioselective, general in scope and produces remarkable building blocks for other chemical transformations.

\section{Introduction}

Harnessing the regioselectivity to quickly access highly functionalized molecules by means of site-selective functional group transformation from adaptable building blocks is essential in synthetic chemistry and biology. Inspired by the broad biological activities of 2,3-dihalogenated phenylacetylene derivatives, ${ }^{1-5}$ only limited synthetic protocols have been reported and none for diiodinated motifs thus far. ${ }^{6-14}$ For instance, a 2,3-diiodinated phenylacetylene derivative (1, Fig. 1) is reported to have cathepsin $\mathrm{K}$ inhibitory action. ${ }^{\mathbf{1 5}}$ Additionally, 2,3-difluorinated diphenylacetylene derivative 2, is reported as allosteric modulator for metabotropic glutamate receptor subtype 5 (mGluR5) for treating neural and psychiatric disorders associated with glutamate dysfunction. ${ }^{3}$ Furthermore, another 2,3-difluorinated diphenylacetylene derivative (3, Fig. 1) are reported to inhibit the proliferation of LS174T colon cancer by inhibition of c-myc and induction of the cyclin-dependent kinase inhibitor., ${ }^{2,16}$ Lastly, 2,3-

${ }^{a}$ Department of Chemistry, Jordan University of Science and Technology, P. O. Box 3030, Irbid, 22110, Jordan. E-mail: rmzoubi@just.edu.jo; Fax: +962-2-7201071; Tel: +962-2-7201000-ext. 23651

${ }^{b}$ Department of Chemistry, Gunning-Lemieux Chemistry Centre, University of Alberta, Edmonton, Alberta, T6G2G2, Canada

$\dagger$ Electronic supplementary information (ESI) available. CCDC 1982244-1982247. For ESI and crystallographic data in CIF or other electronic format see DOI: 10.1039/d0ra01569e dichlorinated phenylacetylene derivative (4, Fig. 1), is found to be useful as selectively active antagonists of $N$-methyl-Daspartate (NMDA) receptor subtypes for treating conditions such as central nervous system trauma, hypoglycemia, anxiety, stroke, convulsions, cerebral ischemia, chronic pain or neurodegenerative disorders as Alzheimer's Disease, Parkinsonism and Huntington's disease. ${ }^{5}$

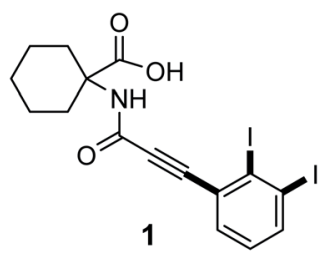

Cathepsin K inhibitory

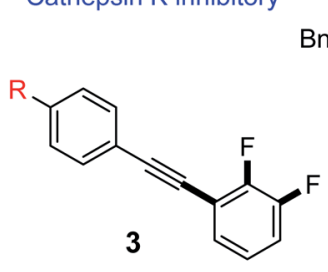

Anticancer agents $\mathrm{R}=\mathrm{H}$, isopropyl

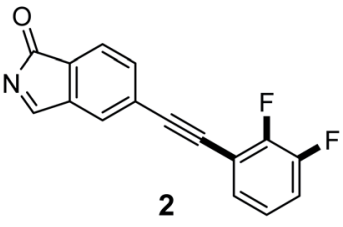

Allosteric modulators of

$\mathrm{Bn}$ mGLUR5

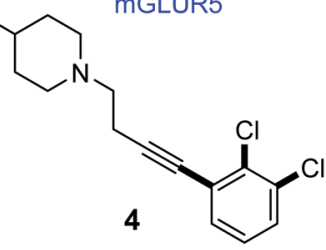
antagonists
Selective NMDA receptor

Fig. 1 Some biologically active 2,3-dihalogenated phenylacetylene compounds in medicine. 


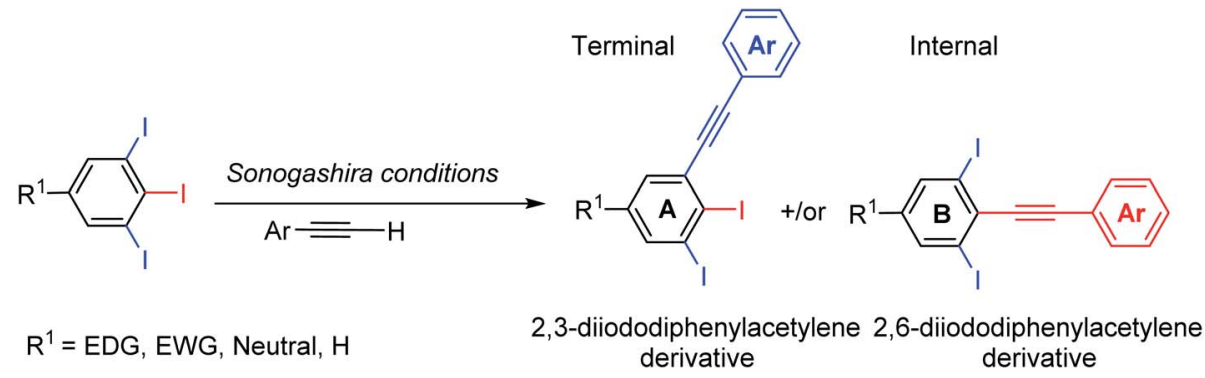

Scheme 1 Possible diiodinated diphenylacetylene regioisomers from Sonogashira cross-coupling of 5-substituted-1,2,3-triiodoarenes.

The status quo of these 2,3-dihalogenated phenylacetylenes and other derivatives ${ }^{17,18}$ with their remarkable applications in medicine encouraged us for developing a new method to access 2,3-diiodinated phenylacetylene molecules. Although few reports for the synthesis of 2,3-dihalogenated phenylacetylenes were published, no protocol for the synthesis of 2,3-diiodinated diphenylacetylene motifs is reported to date. Herein, we report the first synthetic method to access hitherto unknown 2,3-diiodinated diphenylacetylene derivatives by regioselective Sonogashira cross-coupling of 5-substituted-1,2,3-triiodobenzene that is efficient, scalable and affords moderate to good yields.

A broad functional groups were examined under the optimized reaction conditions and found tolerant providing the desired terminal coupling products in highly regioselective manner that are indeed difficult to make by alternative means.

\section{Results and discussion}

Considering the remarkable bioactivities of many 2,3-dihalogenated phenylacetylene derivatives in literature and also to our finding in regioselective Suzuki-Miyaura cross-coupling of 5substituted-1,2,3-triiodobenzene, ${ }^{19}$ we felt impelled to examine the Sonogashira cross-couplings on 5-substituted-1,2,3triiodobenzenes aiming forward to diiodinated phenylacetylene derivatives. 5-Substituted-1,2,3-triiodobenzene starting materials were prepared according to our previous procedures from anilines or benzoic acids. ${ }^{20-22}$

Several regioselective Sonogashira of polyhalogenated arene systems are found in literature. ${ }^{23-32}$ For instance, Langer and coworkers published the synthesis of quinolino $\left[3^{\prime}, 4^{\prime}: 4,5\right]$ pyrrolo $[1,2-f]$ phenanthridines via regioselective Sonogashira of 4chloro-3-iodo-2-methylquinoline with different aryl acetylenes in excellent regioselectivity towards the iodo substituent in moderate to good yields. ${ }^{23}$ Usuki and co-workers reported the total synthesis of desmosine, a biomarker and elastin crosslinker, in 13 steps and $11 \%$ overall yield through sequential regioselective Sonogashira cross-coupling reactions of 3,4,5trihalopyridine. ${ }^{25,26}$ The Sonogashira cross-coupling reaction of 5-substituted-1,2,3-triiodobenzene bearing two regiochemically

Table 1 Conditions for the regioselective Sonogashira cross-coupling reaction of 5-substituted-1,2,3-triiodobenzene 5 and phenylacetylene ${ }^{a}$

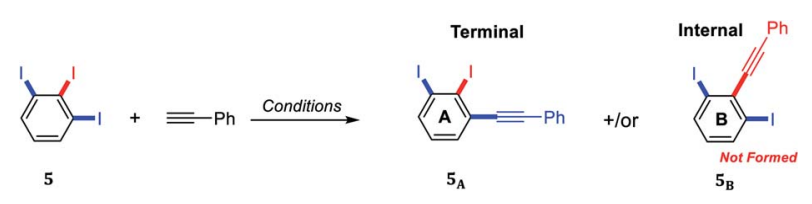

\begin{tabular}{|c|c|c|c|c|c|c|c|}
\hline Entry & Catalyst, co-catalyst (mol\%) & Alkyne (equiv.) & Base (equiv.) & Solvent & $T\left({ }^{\circ} \mathrm{C}\right)$ & Time (h) & $\%$ yield of $\mathbf{5}_{\mathbf{A}}{ }^{b}(\%)$ \\
\hline 1 & $\mathrm{Pd}\left(\mathrm{PPh}_{3}\right)_{4}(10 \%), \mathrm{CuI}(10 \%)$ & 1.2 & $\mathrm{Cs}_{2} \mathrm{CO}_{3}(\mathbf{4})$ & DMF & 100 & 12 & $\mathrm{NS}^{c}$ \\
\hline 2 & $\mathrm{Pd}\left(\mathrm{PPh}_{3}\right)_{4}(10 \%), \mathrm{CuI}(10 \%)$ & 1.0 & $\mathrm{Cs}_{2} \mathrm{CO}_{3}(4)$ & DMF & 100 & 12 & $\mathrm{NS}^{c}$ \\
\hline 4 & $\mathrm{Pd}\left(\mathrm{PPh}_{3}\right)_{4}(10 \%), \mathrm{CuI}(10 \%)$ & 1.0 & $\mathrm{Cs}_{2} \mathrm{CO}_{3}(4)$ & DMF & 25 & 12 & $\mathrm{NS}^{c}$ \\
\hline 5 & $\mathrm{Pd}\left(\mathrm{PPh}_{3}\right)_{4}(10 \%), \mathrm{CuI}(10 \%)$ & 1.0 & DMAP (4) & DMF & 25 & 12 & $0 \%$ \\
\hline 6 & $\mathrm{Pd}\left(\mathrm{PPh}_{3}\right)_{4}(10 \%), \mathrm{CuI}(10 \%)$ & 1.0 & $\mathrm{Cs}_{2} \mathrm{CO}_{3}(4)$ & Toluene & 25 & 12 & $15 \%$ \\
\hline 9 & $\mathrm{Pd}\left(\mathrm{PPh}_{3}\right)_{4}(10 \%), \mathrm{CuI}(20 \%)$ & 1.0 & $\mathrm{Cs}_{2} \mathrm{CO}_{3}(4)$ & Toluene & 25 & 24 & $37 \%$ \\
\hline 10 & $\operatorname{Pd}\left(\mathrm{PPh}_{3}\right)_{4}(10 \%), \mathrm{CuI}(20 \%)$ & 1.0 & $\mathrm{Cs}_{2} \mathrm{CO}_{3}(7)$ & Toluene & 25 & 24 & $60 \%$ \\
\hline 11 & $\mathrm{Pd}\left(\mathrm{PPh}_{3}\right)_{4}(10 \%), \mathrm{CuI}(20 \%)$ & 1.0 & $\mathrm{Cs}_{2} \mathrm{CO}_{3}(10)$ & Toluene & 25 & 24 & $58 \%$ \\
\hline 12 & $\mathrm{Pd}\left(\mathrm{PPh}_{3}\right)_{4}(5 \%), \mathrm{CuI}(20 \%)$ & 1.0 & $\mathrm{Cs}_{2} \mathrm{CO}_{3}(7)$ & Toluene & 25 & 24 & $42 \%$ \\
\hline 13 & $\mathrm{Pd}\left(\mathrm{PPh}_{3}\right)_{4}(10 \%), \mathrm{CuI}(20 \%)$ & 1.0 & $\mathrm{~K}_{2} \mathrm{CO}_{3}(7)$ & Toluene & 25 & 24 & $49 \%$ \\
\hline $14^{e}$ & $\mathrm{Pd}\left(\mathrm{PPh}_{3}\right)_{4}(10 \%), \mathrm{CuI}(20 \%)$ & 1.0 & $\mathrm{Cs}_{2} \mathrm{CO}_{3}(7)$ & Toluene & 25 & 24 & $53 \%$ \\
\hline
\end{tabular}

${ }^{a}$ Conditions: all recations were carried out using $0.65 \mathrm{mmol}(1.0$ equiv., $0.08 \mathrm{M})$ of $1,2,3$-triiodobenzene $(5)$ in $8.0 \mathrm{~mL}$ anhyd. solvent. ${ }^{b}$ Isolated yield. ${ }^{c}$ NS: not separable mixture of products. ${ }^{d} 5 \%$ of bis-terminal coupling product was isolated. ${ }^{e} 1.0$ gram scale $(2.19 \mathrm{mmol})$. 
unsymmetrical C-I positions provides at most two possible regioisomeric coupling products, the internal and terminal diiodinated diphenylacetylenes (Scheme 1). Consequently, the satisfactory use of $1.0 \mathrm{~mol}$ equivalent of aryl acetylene is adequate to couple one of the three iodo substituents providing the desired diiodinated diphenylacetylene products.

A thorough optimization using 1,2,3-triiodobenzene 5 and phenylacetylene as model substrates to explore this hypothesis as shown in Table 1. Happily and as expected, the reaction was found to be highly regioselective to the terminal $\mathrm{C}-\mathrm{I}$ bond, the more accessible and less hindered position, providing only the 2,3-diiododiphenylacetylene $\mathbf{5}_{\mathbf{A}}$. The order of addition proved to be essential to improve the yield and to minimize the Glaser Homo-coupling side reaction. Temperature and solvent were also found to be essential parameters in our optimization. The reaction of 1,2,3-triiodobenzene 5 with 1.2 equiv. of phenylacetylene in DMF at $100{ }^{\circ} \mathrm{C}$ provided a non clean reaction forming other side reactions and Glaser homo-coupling product (Table 1,

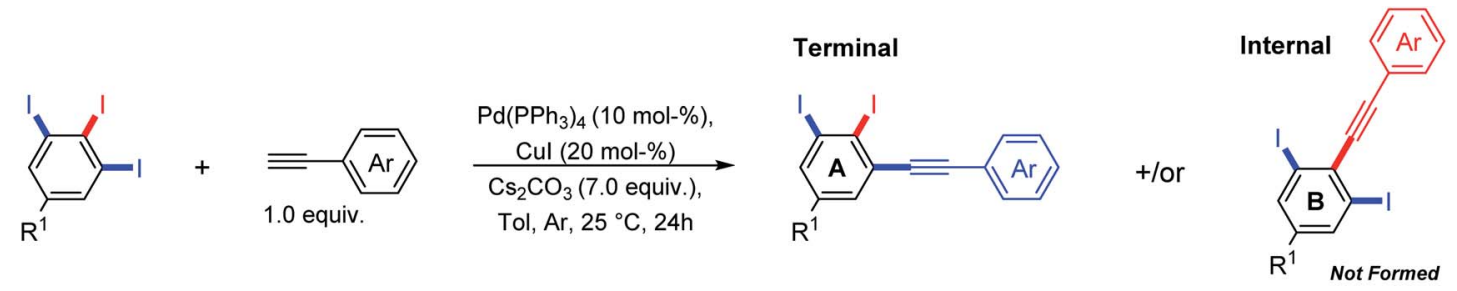

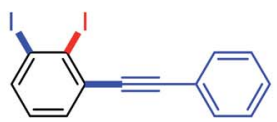

$\mathbf{5}_{\text {A }}, 60 \%$

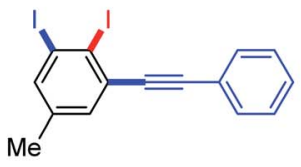

$\mathbf{9}_{\text {A }}, 51 \%$

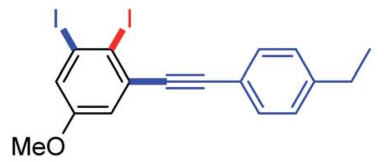

$13_{\text {A }}, 29 \%$

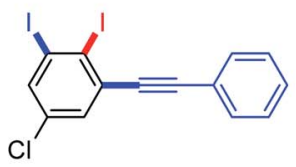

17 A, $42 \%$

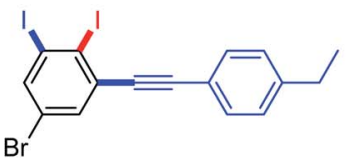

$21_{\text {A }}, 85 \%$

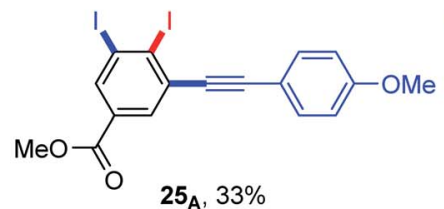

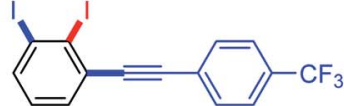

6. $51 \%$

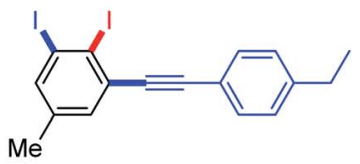

10 A $85 \%$

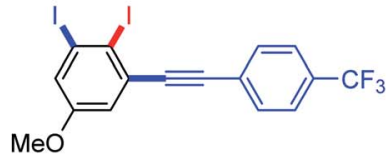

14 A, $36 \%$

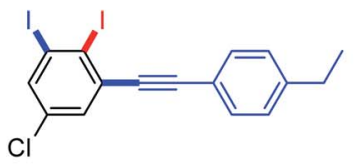

18 A, $34 \%$

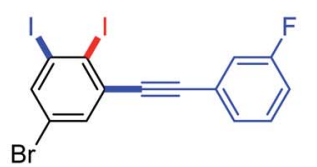

22 A, 44\%

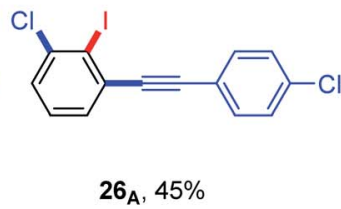

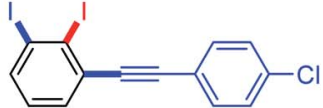

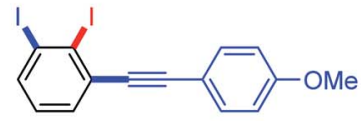

$7_{\text {A }}, 37 \%$

$8_{\text {A }}, 41 \%^{b}$

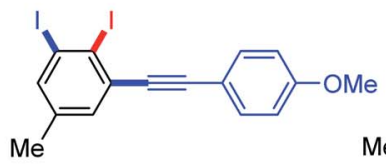

$11_{A}, 42 \%$

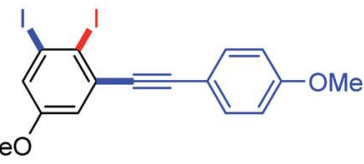

12 A, $51 \%^{b}$<smiles>COc1cc(I)c(I)c(C#Cc2ccc(F)cc2)c1</smiles>

$15_{\text {A }}, 27 \%$

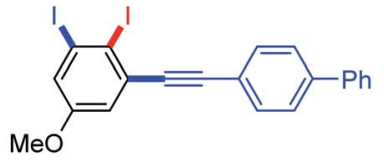

$16_{\text {A }}, 51 \%$

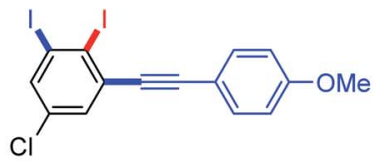

19 A, $44 \%$

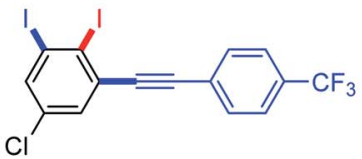

$20_{\text {A }}, 31 \%^{b}$

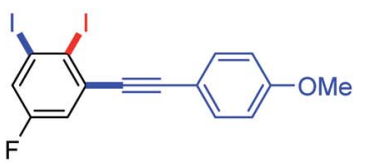

23 A $74 \%$

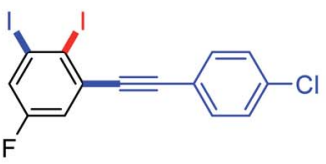

$24_{\text {A }}, 62 \%$

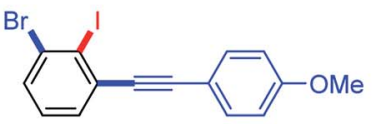

$27_{\text {A }}, 62 \%$

Scheme 2 Terminal vs. internal diiodinated diphenylacetylene derivatives via regioselective Sonogashira cross-coupling of 5-substituted-1,2,3triiodobenzenes and arylcetylenes. ${ }^{a}$ Yields are given for isolated compounds (reaction scale: 0.65 mmol). ${ }^{b} 5-10 \%$ of meta bis-terminal coupling product was isolated. 
entries 1 and 2). It is worth mentioning that due to the low polarity of the desired product, a difficult purification was observed in the presence of Glaser homo-coupling product. At elevated temperature such as $100{ }^{\circ} \mathrm{C}$, it is not surprising that significant amount of multiple coupling reactions with other $\mathrm{C}-\mathrm{I}$ bonds and other side reactions were possibly formed. Lowering the reaction temperature to $50{ }^{\circ} \mathrm{C}$ and $25{ }^{\circ} \mathrm{C}$ were found to be unsuccessful (Table 1, entry 3 and 4). Changing the base to 4(dimethylamino)pyridine (DMAP) shutdown the reaction (Table 1, entry 5). Changing the solvent to anhydrous toluene provided the wanted product $\mathbf{5}_{\mathbf{A}}$ in $15 \%$ yield (Table 1 , entry 6 ). Elongate reaction time to 24 hours at same temperature provided $29 \%$ (Table 1, entry 7). Increasing the $\mathrm{Pd}\left(\mathrm{PPh}_{3}\right)_{4}$ loading to $20 \mathrm{~mol} \%$ gave $21 \%$ yield of the desired product with $\sim 5 \%$ of the meta biscoupled product (Table 1, entry 8 ). While increasing the CuI loading to $20 \mathrm{~mol} \%$ was found to be beneficial provided $37 \%$ yield of the desired product $\mathbf{5}_{\mathbf{A}}$ (Table 1 , entry 9 ). The highest isolated yield for this transformation was achieved by the use of $10 \mathrm{~mol} \%$ of $\mathrm{Pd}\left(\mathrm{PPh}_{3}\right)_{4}, 20 \mathrm{~mol} \%$ of $\mathrm{CuI}$ as a co-catalysis, 7.0 equiv. of $\mathrm{Cs}_{2} \mathrm{CO}_{3}$ as a base in anhydrous toluene at $25^{\circ} \mathrm{C}$ for $24 \mathrm{~h}$ (Table 1 , entry 10). Other conditions were found to be unsuccessful to further enhance the reaction (Table 1, entries 11-13). The coupling reaction over and above performed nicely on large scale
(Table 1, entry 14). The scope of the regioselective Sonogashira reaction was then studied under the optimized conditions. Therefore, a variety of 5-substituted-1,2,3-triiodobenzene starting materials were examined under the optimized conditions providing the terminal coupling products in excellent siteselectivity (Scheme 2).

It was found that the nature of $\mathrm{R}^{1}$ substituent has a big impact on the reactivity of Sonogashira cross-coupling reactions but not on regioselectivity. A combination between electronpoor/neutral 1,2,3-triiodoarenes and electron-rich arylacetylenes provided the terminal coupling products in high isolated yields (Scheme 2: $\mathbf{1 0}_{\mathbf{A}}, \mathbf{2 1}_{\mathbf{A}}, \mathbf{2 3}_{\mathbf{A}}$ and $\mathbf{2 4}_{\mathbf{A}}$ ). In contrast, electronrich 1,2,3-triiodoarenes afforded moderate yields (Scheme 2: $\left.\mathbf{1 2}_{\mathbf{A}} \mathbf{- 1 6} \mathbf{A}\right)$. The formation of the internal coupling regioisomer was not detected in all examples (Scheme 2: B). Gratefully, the coupling reaction with bromo or chloro substituents was not observed (Scheme 2: $\mathbf{1 7} \mathbf{A}_{\mathbf{A}}-\mathbf{2 2} \mathbf{A}$ and $\mathbf{2 6} \mathbf{6}_{\mathbf{A}}-\mathbf{2 7} \mathbf{A}$ ) and it can tolerate a wide range of functional groups. $5-10 \%$ of the meta bisterminal coupling products were isolated in some cases (Scheme 2: $\mathbf{6}_{\mathbf{A}}, \mathbf{8}_{\mathbf{A}}, \mathbf{1 2}_{\mathrm{A}}$ and $2 \mathbf{0}_{\mathbf{A}}$ ).

The structure of 2,3-diiodinated diarylacetylene compounds are further confirmed by X-ray diffraction methods for three coupling products, 1,2-diiodo-3-((4-(trifluoromethyl)phenyl)

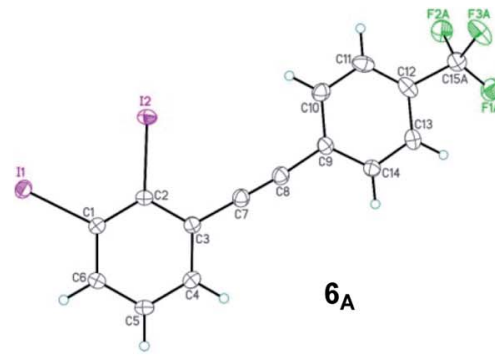

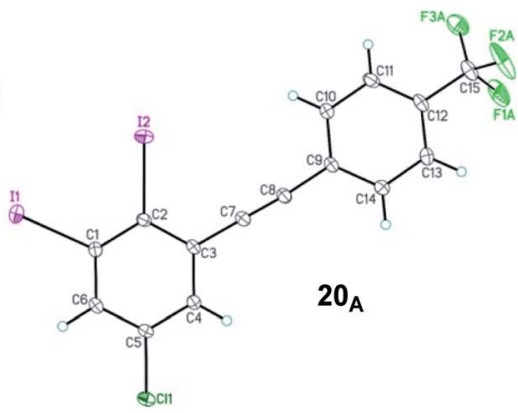

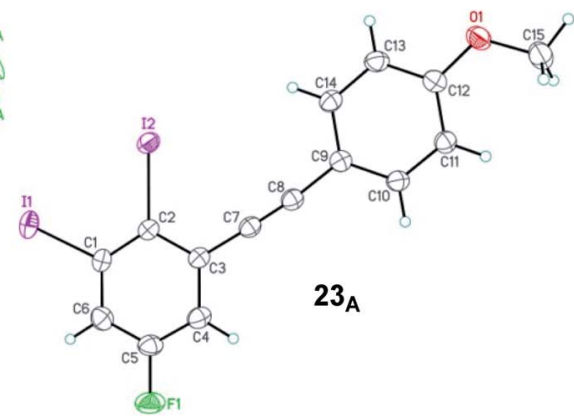

Fig. 2 ORTEP view of 1,2-diiodo-3-((4-(trifluoromethyl)phenyl)ethynyl)benzene $6_{A}, 5$-chloro-1,2-diiodo-3-((4-(trifluoromethyl)phenyl)ethynyl) benzene $20_{\mathrm{A}}$ and 5-fluoro-1,2-diiodo-3-((4-mehthoxyphenyl)ethynyl)benzene $23_{\mathrm{A}}$. Thermal Gaussian ellipsoids at 30\% probability level.

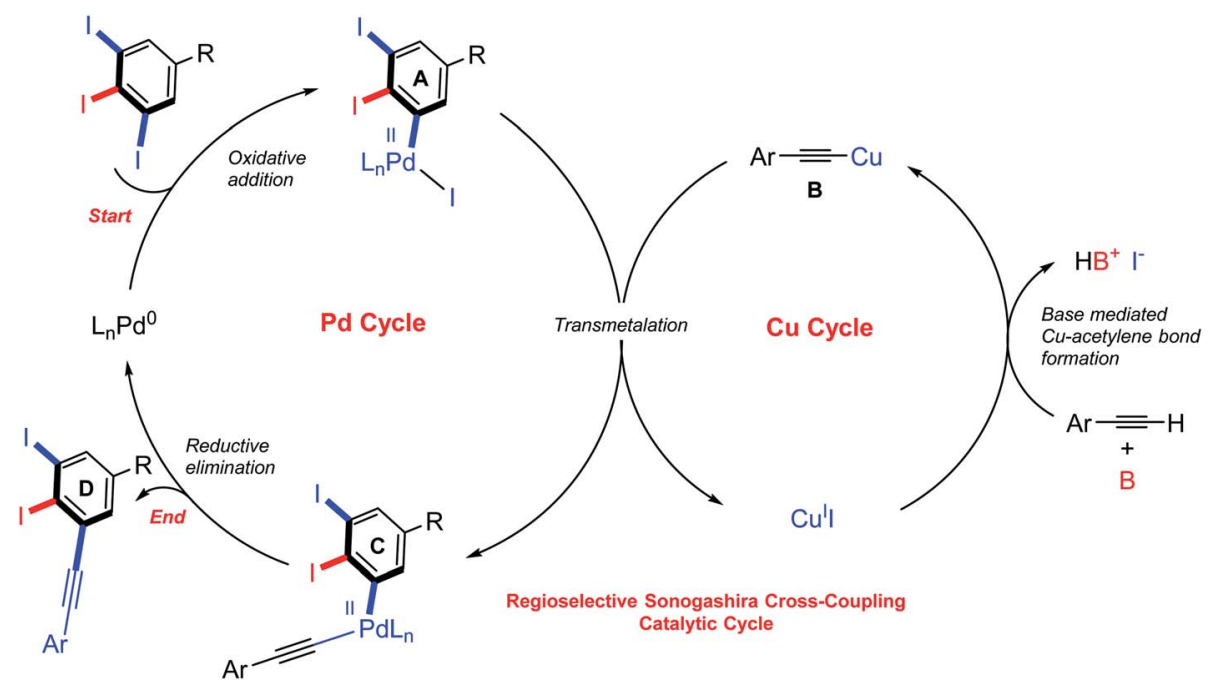

Scheme 3 Proposed catalytic cycle for regioselective Sonogashira cross-coupling reaction of 5-substituted-1,2,3-triiodobenzene. 

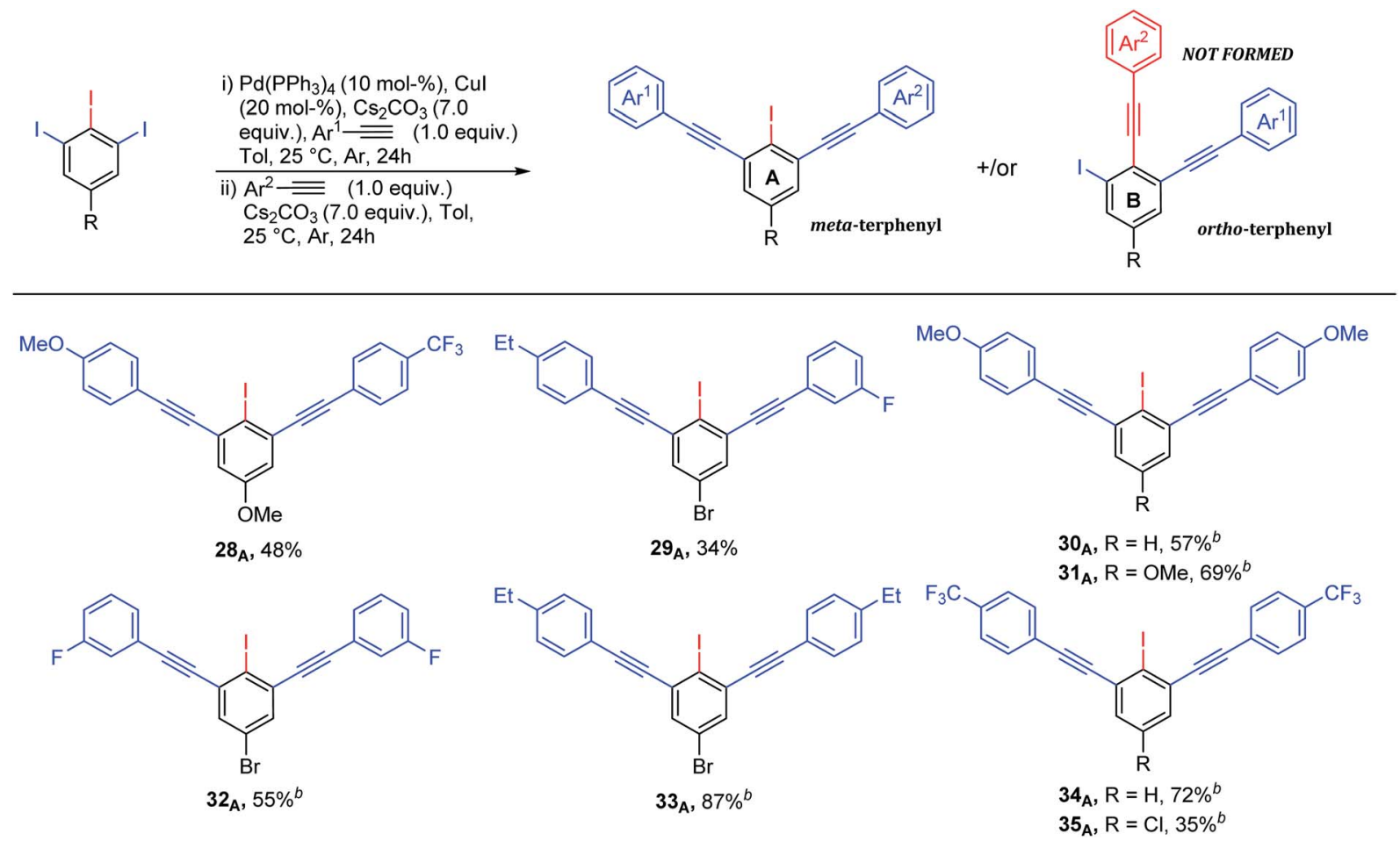

Scheme 4 lodinated terphenyls via one-pot double Sonogashira cross-coupling reaction of 1,2,3-triiodoarenes and arylacetylenes. ${ }^{a}$ Yields are given for isolated yields (reaction scale $0.66 \mathrm{mmol}$ ). ${ }^{\mathrm{b}} 2.0$ equiv. of arylacetylene was used.

ethynyl)benzene $\mathbf{6}_{\mathbf{A}}, 5$-chloro-1,2-diiodo-3-((4-(trifluoromethyl) phenyl)ethynyl) benzene $\quad \mathbf{2 0}_{\mathrm{A}}$ and 5 -fluoro-1,2-diiodo-3-((4methoxyphenyl)ethynyl) benzene $2 \mathbf{3}_{\mathrm{A}}$ as shown in Fig. $2 .^{33}$

Although various approaches for regioselective Sonogashira cross-coupling have been previously reported, ${ }^{34-46}$ a plausible catalytic cycle for regioselective Sonogashira cross-coupling of 5-substituted-1,2,3-triiodobenzene is proposed in Scheme 3. Oxidative addition by $\mathrm{Pd}^{0}$ at the terminal C-I position, the less sterically hindered and more accessible position forming $\mathrm{Pd}^{\mathrm{II}}$ intermediate $\mathbf{A}$. The transmetallation of $\mathrm{Pd}^{\mathrm{II}}$ intermediate $\mathbf{A}$ with copper(I) acetylide $\mathbf{B}$, which was in situ generated with base and $\mathrm{Cu}^{\mathrm{II}}$, to afford $\mathrm{Pd}^{\mathrm{II}}$ intermediate $\mathbf{C}$. Reductive elimination afforded the terminal coupled product $\mathbf{D}$ and regenerated the catalyst for another catalytic cycle. We then turn our attentions to examine the reactivity order of the other iodo groups under the optimized conditions. Therefore, one-pot double Sonogashira cross-coupling reactions of 5-substituted-1,2,3triiodobenzene with 2.0 equiv. of arylacetylenes were performed. The excellent regioselectivity of the first coupling, vide supra, promoted the second coupling reaction to occur at the other terminal position providing exclusively the iodinated meta-terphenyl products in moderate to good yields with excellent regioselectivity (Scheme 4: $\mathbf{2 8}_{\mathbf{A}} \mathbf{- 3 5 _ { \mathbf { A } }}$ ). We did not observe the ortho bis-coupled products in all reactions. It is believed that the reaction may proceed via a reversible oxidative addition step.

The structure of bis-coupling products was further supported by X-ray crystallography of one of the derivative, $4,4^{\prime}-((5-$ chloro-2-iodo-1,3-phenylene)bis(ethyne-2,1-diyl))

bis((trifluoromethyl)benzene) $\mathbf{3 5}_{\mathbf{A}}$ as shown in Fig. $3 .^{33}$

The quickly access of highly functionalized compounds from available starting materials is crucial in academia and industry. The 1,2,3-trisubstituted benzenes are demanded and challenging derivatives in literature. Therefore, 2,3-diiododiphenylacetylene $\mathbf{5}_{\mathbf{A}}$ was used to quickly access 1,2,3trisubstitutedbenzene derivatives using Suzuki-Miyaura crosscoupling reactions (Scheme 5).

The use of 2.0 mol equiv. of arylboronic acid under the optimized conditions,$^{19}$ provided the trisubstituted derivatives (Scheme 5: 36-37) through one-pot double Suzuki-Miyaura cross-coupling in good isolated yields. It is worth noting that the use of 1.0 mol equiv. of arylboronic acid under the same

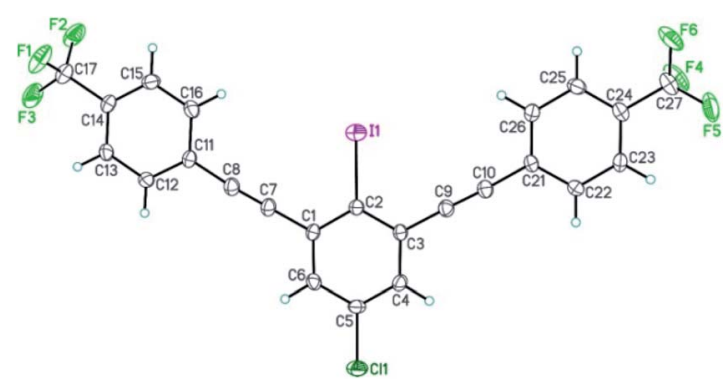

Fig. 3 ORTEP view of 4,4'-((5-chloro-2-iodo-1,3-phenylene)bis(ethyne-2,1-diyl))bis((trifluoromethyl)benzene) $35_{\mathrm{A}}$. Thermal Gaussian ellipsoids at $30 \%$ probability level. 


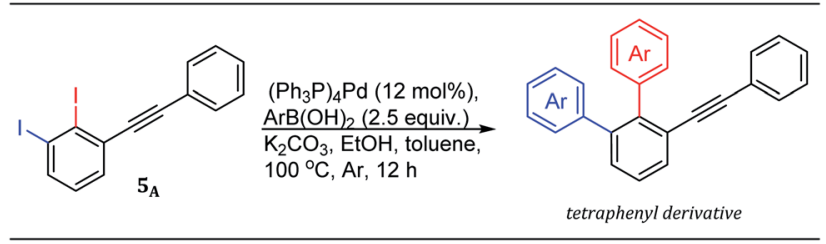

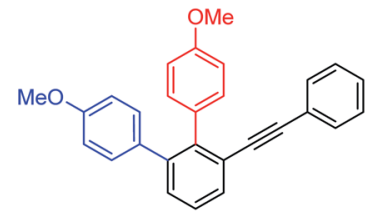

$36,55 \%$

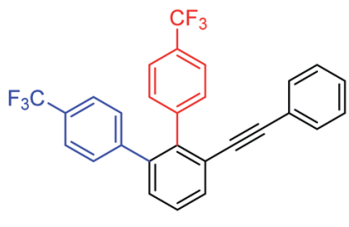

$37,63 \%$
Scheme 5 Tetraphenyls via one-pot double Suzuki-Miyaura crosscoupling reaction of 1,2-diiodo-3-(phenylethynyl)benzene $5_{\mathrm{A}}$. ${ }^{\text {aYields }}$ are given for isolated yields (reaction scale $0.66 \mathrm{mmol}$ ).

conditions is found to be inefficient providing a non separable mixture of $\sim 1: 1$ of both coupling products.

\section{Conclusion}

In summary, we reported the first synthesis of hitherto unknown 2,3-diiodinated diphenylacetylene and iodinated meta terphenylacetylene derivatives via highly regioselective mono and double Sonogashira cross-coupling reaction from 5substituted-1,2,3-triiodobenzene. The desired products were isolated in moderate to good yields (17-85\%) and the reaction tolerated a broad range of functional groups. No coupling reaction with bromo or chloro groups was observed. The regioselectivity of coupling reactions exclusively performed at the terminal C-I bonds, the less sterically hindered and the most regioactive positions. The highest isolated yields were achieved from reactions of electron-poor/neutral 1,2,3-triiodoarene and electron-rich arylacetylene derivatives. The structure of the products was further supported by X-ray diffraction methods. Having other iodo substituents on these products, further chemical elaborations could easily be explored.

\section{Experimental}

\section{General}

All commercial reagents and chromatography solvents were used as obtained unless otherwise stated. Ethanol, toluene, ethyl acetate, hexanes, anhydrous sodium sulfate $\left(\mathrm{Na}_{2} \mathrm{SO}_{4}, \mathrm{BDH}\right), \mathrm{CuI}$ (Sigma-Aldrich), $\mathrm{Pd}\left(\mathrm{PPh}_{3}\right)_{4}$ (Sigma-Aldrich) were used as received. Anhydrous solvents were distilled over appropriate drying agents prior to use. Analytical thin layer chromatography (TLC) was performed on Merck silica gel $60 \mathrm{~F}_{254}$. Merck silica gel 60 (0.063$0.2 \mathrm{~mm}$ ) was used for column chromatography. Visualization of TLC was accomplished with UV light $(254 \mathrm{~nm})$. NMR spectra were recorded on a Bruker-Avance $400 \mathrm{MHz}$ spectrometer. The residual solvent protons $\left({ }^{1} \mathrm{H}\right)$ or the solvent carbon $\left({ }^{13} \mathrm{C}\right)$ were used as internal standards. ${ }^{1} \mathrm{H}-\mathrm{NMR}$ data are presented as follows: chemical shift in $\mathrm{ppm}(\delta)$ downfield from trimethylsilane (multiplicity, integration, coupling constant). The following abbreviations are used in reporting NMR data: s, singlet; bs, broad singlet; d, doublet; t, triplet; q, quartet; dq, doublet of quartets; dd, doublet of doublets; m, mutiplet. High resolution mass spectra were recorded using Chemical Ionization (CI) and electrospray ionization (ESI) techniques.

\section{General procedure for Sonogashira cross-coupling reactions of 5-substituted-1,2,3-triiodobenzenes}

A flame-dried Schlenk flask was charged with 5-substituted1,2,3-triiodobenzene ( $0.65 \mathrm{mmol}, 0.08 \mathrm{M}, 1.0$ equiv.), aryl acetylene (1.0 equiv.), $\mathrm{Cs}_{2} \mathrm{CO}_{3}$ (7.0 equiv.) in $8.0 \mathrm{~mL}$ dry toluene. The mixture was stirred under argon at room temperature for $20 \mathrm{~min}$. Tetrakis(triphenylphosphine)palladium (0) (10 mol\%) and copper iodide (20 mol\%) were added, capped with septum, carefully degassed with argon, and the reaction flask was wrapped with aluminum foil and stirred at room temperature for $24 \mathrm{~h}$. The reaction mixture was then diluted with EtOAc and filtered over Celite $545 \circledast$. Distilled water $(100 \mathrm{~mL})$ was added and extracted with EtOAc $(2 \times 50 \mathrm{~mL})$. The organic layers were combined, washed with brine, dried with anhyd. $\mathrm{Na}_{2} \mathrm{SO}_{4}$, filtered and evaporated under reduced pressure. The crude product was purified by flash chromatography ( $100 \%$ hexane) to yield the pure desired product.

\section{Synthesis of 1,2-diiodo-3-(phenylethynyl)benzene ( $\left.5_{A}\right)$}

The title compound was synthesized using the general procedure and isolated in $60 \%$ yield as colorless oil after flash chromatography. IR (cast film, $\mathrm{cm}^{-1}$ ) 3087, 3046, 2201, 1599, 1523, 912, 837, 749, 624. $\delta_{\mathrm{H}}\left(400 \mathrm{MHz}, \mathrm{CDCl}_{3}\right) \delta: 7.81(\mathrm{~d}, 1 \mathrm{H}, J=7.9 \mathrm{~Hz})$, 7.50-7.65 (m, 2H), $7.47(\mathrm{~d}, 1 \mathrm{H}, J=7.6 \mathrm{~Hz}), 7.30-7.40(\mathrm{~m}, 3 \mathrm{H}), 7.03$ $(\mathrm{dd}, 1 \mathrm{H}, J=7.8 \mathrm{~Hz}) . \delta_{\mathrm{C}}\left(100 \mathrm{MHz}, \mathrm{CDCl}_{3}\right) \delta: 138.9,131.9,131.8$, 131.3, 129.2, 129.0, 128.6, 122.8, 114.7, 108.9, 93.5, 93.1. HRMS (EI) $\mathrm{m} / \mathrm{z}$ for $\mathrm{C}_{14} \mathrm{H}_{8} \mathrm{I}_{2}[\mathrm{M}]^{+}$: calcd 429.8715 ; found, 429.8709 .

\section{Synthesis of 1,2-diiodo-3-((4-(trifluoromethyl)phenyl)ethynyl) benzene $\left(6_{A}\right)$}

The title compound was synthesized using the general procedure and isolated in $\mathbf{5 1 \%}$ yield as white solid after flash chromatography. IR (cast film, $\mathrm{cm}^{-1}$ ) 3109, 3046, 2204, 1588, 1541, 1042, 943, 812, 738, 661. $\delta_{\mathrm{H}}\left(400 \mathrm{MHz} \mathrm{CDCl}_{3}\right) \delta: 7.85(\mathrm{~d}, 1 \mathrm{H}$, $J=7.9 \mathrm{~Hz}), 7.68(\mathrm{~d}, 2 \mathrm{H}, J=8.0 \mathrm{~Hz}), 7.62(\mathrm{~d}, 2 \mathrm{H}, J=8.2 \mathrm{~Hz}), 7.48$ $(\mathrm{d}, 1 \mathrm{H}, J=7.6), 7.06\left(\mathrm{dd}, 1 \mathrm{H}, J^{1}=7.8 \mathrm{~Hz}, J^{2}=7.7 \mathrm{~Hz}\right) . \delta_{\mathrm{C}}(100$ $\mathrm{MHz} \mathrm{CDCl}_{3}$ ) $\delta: 139.5,132.0,131.6,131.2,130.7$ (q, $\left.J_{\mathrm{C}-\mathrm{F}}=33 \mathrm{~Hz}\right)$, 129.3, 126.6, 125.5 (q, $\left.J_{\mathrm{C}-\mathrm{F}}=4 \mathrm{~Hz}\right), 124.0\left(\mathrm{q}, J_{\mathrm{C}-\mathrm{F}}=271 \mathrm{~Hz}\right)$, 114.8, 109.1, 95.6, 91.4. Mp: 92-94 ${ }^{\circ} \mathrm{C}$. HRMS (EI) $\mathrm{m} / \mathrm{z}$ for $\mathrm{C}_{15} \mathrm{H}_{7} \mathrm{~F}_{3} \mathrm{I}_{2}[\mathrm{M}]^{+}$: calcd 497.8589; found, 497.8576 .

\section{Synthesis of 1-((4-chlorophenyl)ethynyl)-2,3-diiodobenzene}

$\left(7_{\mathbf{A}}\right)$

The title compound was synthesized using the general procedure and isolated in $\mathbf{3 7 \%}$ yield as white solid after flash chromatography. IR (cast film, $\mathrm{cm}^{-1}$ ) 3086, 3012, 2203, 914, 824, 748, 638. $\delta_{\mathrm{H}}$ $\left(400 \mathrm{MHz}, \mathrm{CDCl}_{3}\right) \delta: 7.81(\mathrm{~d}, 1 \mathrm{H}, J=7.8 \mathrm{~Hz}), 7.40-7.60(\mathrm{~m}, 3 \mathrm{H})$, $7.32(\mathrm{~d}, 2 \mathrm{H}, J=8.4 \mathrm{~Hz}), 7.03(\mathrm{dd}, 1 \mathrm{H}, J=7.8 \mathrm{~Hz}, J=7.7 \mathrm{~Hz}) . \delta_{\mathrm{C}}$ 
$\left(100 \mathrm{MHz}, \mathrm{CDCl}_{3}\right) \delta: 139.2,135.2,133.0,131.6,131.4,129.2,129.0$, 121.2, 114.7, 109.0, 94.4, 91.9. Mp: $101-103{ }^{\circ} \mathrm{C}$. HRMS (EI) $\mathrm{m} / \mathrm{z}$ for $\mathrm{C}_{14} \mathrm{H}_{7} \mathrm{ClI}_{2}[\mathrm{M}]^{+}$: calcd 463.8326; found, 463.8317 .

\section{Synthesis of 1,2-diiodo-3-((4-methoxyphenyl)ethynyl)benzene} $\left(\mathbf{8}_{\mathrm{A}}\right)$

The title compound was synthesized using the general procedure and isolated in $\mathbf{4 1 \%}$ yield as white solid after flash chromatography. IR (cast film, $\mathrm{cm}^{-1}$ ) 3087, 3024, 2215, 1606, 1546, $1324,1157,973,843,642 . \delta_{\mathrm{H}}\left(400 \mathrm{MHz}, \mathrm{CDCl}_{3}\right) \delta: 7.78(\mathrm{~d}, 1 \mathrm{H}, J=$ $7.8 \mathrm{~Hz}), 7.51(\mathrm{~d}, 2 \mathrm{H}, J=8.7 \mathrm{~Hz}), 7.44(\mathrm{~d}, 1 \mathrm{H}, J=7.6 \mathrm{~Hz}), 7.02(\mathrm{dd}$, $\left.1 \mathrm{H}, J^{1}=7.7 \mathrm{~Hz}, J^{2}=7.8 \mathrm{~Hz}\right), 6.89(\mathrm{~d}, 2 \mathrm{H}, J=8.7 \mathrm{~Hz}) . \delta_{\mathrm{C}}(100$ $\left.\mathrm{MHz}, \mathrm{CDCl}_{3}\right) \delta: 160.3,138.6,133.3,132.3,131.1,129.2,114.9$, 114.6, 114.3, 108.9, 93.4, 92.5, 55.5. Mp: 82-84 ${ }^{\circ} \mathrm{C}$. HRMS (EI) $\mathrm{m} /$ $z$ for $\mathrm{C}_{15} \mathrm{H}_{10} \mathrm{I}_{2} \mathrm{O}[\mathrm{M}]^{+}$: calcd 459.8821; found, 459.8814 .

\section{Synthesis of 1,2-diiodo-5-methyl-3-(phenylethynyl)benzene (9)}

The title compound was synthesized using the general procedure and isolated in $\mathbf{5 1 \%}$ yield as colorless oil after flash chromatography. IR (cast film, $\mathrm{cm}^{-1}$ ) 3086, 3015, 2209, 1604, 1573, 784, 652, 507. $\delta_{\mathrm{H}}\left(400 \mathrm{MHz}, \mathrm{CDCl}_{3}\right) \delta: 7.67(\mathrm{~d}, 1 \mathrm{H}, J=1.1 \mathrm{~Hz})$, 7.56-7.59 (m, 2H), 7.36-7.37 (m, 3H), $7.30(\mathrm{~d}, 1 \mathrm{H}, J=1.1 \mathrm{~Hz})$, $2.24(\mathrm{~s}, 3 \mathrm{H}) . \delta_{\mathrm{C}}\left(100 \mathrm{MHz}, \mathrm{CDCl}_{3}\right) \delta: 139.9,139.5,132.4,131.8$, 131.3, 129.0, 128.6, 122.8, 110.5, 108.8, 93.5, 92.7, 20.4. HRMS (EI) $m / z$ for $\mathrm{C}_{15} \mathrm{H}_{10} \mathrm{I}_{2}[\mathrm{M}]^{+}$: calcd 443.8872 ; found, 443.8867 .

\section{Synthesis of 1-((4-ethylphenyl)ethynyl)-2,3-diiodo-5-methyl benzene $\left(10_{\mathrm{A}}\right)$}

The title compound was synthesized using the general procedure and isolated in $\mathbf{8 5 \%}$ yield as colorless oil after flash chromatography. IR (cast film, $\mathrm{cm}^{-1}$ ) 3104, 3086, 3042, 2198, 1594, 1546, 964, 862, 779, 634. $\delta_{\mathrm{H}}\left(400 \mathrm{MHz}, \mathrm{CDCl}_{3}\right) \delta: 7.65(\mathrm{~s}, 1 \mathrm{H})$, $7.49(\mathrm{~d}, 2 \mathrm{H}, J=8.0 \mathrm{~Hz}), 7.29$ (d, $1 \mathrm{H}, J=1.0 \mathrm{~Hz}), 7.19(\mathrm{~d}, 2 \mathrm{H}$, $J=8.0 \mathrm{~Hz}), 2.64-2.70(\mathrm{~m}, 2 \mathrm{H}), 2.23(\mathrm{~s}, 3 \mathrm{H}), 1.23-1.27(\mathrm{~m}, 3 \mathrm{H}) . \delta_{\mathrm{C}}$ $\left(100 \mathrm{MHz} \mathrm{CDCl}_{3}\right) \delta: 145.5,139.7,139.5,132.7,132.3,131.8$, 131.5, 128.1, 120.0, 110.5, 108.7, 93.0, 29.1, 20.4, 15.5. HRMS (EI) $\mathrm{m} / z$ for $\mathrm{C}_{17} \mathrm{H}_{14} \mathrm{I}_{2}[\mathrm{M}]^{+}$: calcd 471.9185; found, 471.9182 .

\section{Synthesis of 1,2-diiodo-3-((4-methoxyphenyl)ethynyl)-5-methyl benzene $\left(11_{A}\right)$}

The title compound was synthesized using the general procedure and isolated in $\mathbf{4 2} \%$ yield as white solid after flash chromatography. IR (cast film, $\mathrm{cm}^{-1}$ ) 3107, 3056, 2205, 1614, 1573, 1168, 1021, 983, 673. $\delta_{\mathrm{H}}\left(400 \mathrm{MHz}, \mathrm{CDCl}_{3}\right) \delta: 7.64(\mathrm{~s}, 1 \mathrm{H}), 7.51(\mathrm{~d}$, $2 \mathrm{H}, J=8.7 \mathrm{~Hz}), 7.27(\mathrm{~s}, 1 \mathrm{H}), 6.89(\mathrm{~d}, 2 \mathrm{H}, J=8.7 \mathrm{~Hz}), 3.83(\mathrm{~s}, 3 \mathrm{H})$, $2.23(\mathrm{~s}, 3 \mathrm{H}) . \delta_{\mathrm{C}}\left(100 \mathrm{MHz}, \mathrm{CDCl}_{3}\right) \delta: 160.2,139.5,139.4,133.3$, 132.1, 131.6, 114.9, 114.2, 110.4, 108.7, 92.9, 92.5, 55.5, 20.4. Mp: 91-93 ${ }^{\circ} \mathrm{C}$ HRMS (EI) $m / z$ for $\mathrm{C}_{16} \mathrm{H}_{12} \mathrm{I}_{2} \mathrm{O}[\mathrm{M}]^{+}$: calcd 473.8978; found, 473.8974 .

\section{Synthesis of 1,2-diiodo-5-methoxy-3-((4-methoxyphenyl) ethynyl)benzene $\left(12_{A}\right)$}

The title compound was synthesized using the general procedure and isolated in $\mathbf{5 1 \%}$ yield as white solid after flash chromatography (5\% EtOAc/hexane) using the general procedure. IR (cast film, $\mathrm{cm}^{-1}$ ) 3042, 3012, 2195, 1594, 1548, 1209, $1168,1023,918,652 . \delta_{\mathrm{H}}\left(400 \mathrm{MHz}, \mathrm{CDCl}_{3}\right) \delta: 7.52(\mathrm{~d}, 2 \mathrm{H}, J=8.6$ $\mathrm{Hz}), 7.39(\mathrm{~d}, 1 \mathrm{H}, J=2.8 \mathrm{~Hz}), 7.02(\mathrm{~d}, 1 \mathrm{H}, J=2.7 \mathrm{~Hz}), 6.89(\mathrm{~d}, 2 \mathrm{H}$, $J=8.6 \mathrm{~Hz}), 3.83(\mathrm{~s}, 3 \mathrm{H}), 3.78(\mathrm{~s}, 3 \mathrm{H}) . \delta_{\mathrm{C}}\left(100 \mathrm{MHz}, \mathrm{CDCl}_{3}\right) \delta$ : 160.3 , 159.4, 133.3, 131.9, 125.6, 117.1, 114.7, 114.3, 108.8, 103.6, 93.1, 92.5, 55.8, 55.5. Mp: $83-85{ }^{\circ} \mathrm{C}$. HRMS (EI) $m / z$ for $\mathrm{C}_{16} \mathrm{H}_{12} \mathrm{I}_{2} \mathrm{O}_{2}[\mathrm{M}]^{+}$: calcd exact 489.8927 ; found 489.8921 .

\section{Synthesis of 1-((4-ethylphenyl)ethynyl)-2,3-diiodo-5-methoxy benzene $\left(13_{\mathrm{A}}\right)$}

The title compound was synthesized using the general procedure and isolated in $\mathbf{2 9 \%}$ yield as white solid after flash chromatography. IR (cast film, $\mathrm{cm}^{-1}$ ) 3059, 3024, 2212, 1584, 1542, $1145,1048,956,768 . \delta_{\mathrm{H}}\left(400 \mathrm{MHz}, \mathrm{CDCl}_{3}\right) \delta: 7.50(\mathrm{~d}, 2 \mathrm{H}, J=8.0$ $\mathrm{Hz}), 7.40(\mathrm{~d}, 1 \mathrm{H}, J=2.8), 7.20(\mathrm{~d}, 2 \mathrm{H}, J=7.8), 7.04(\mathrm{~d}, 1 \mathrm{H}$, $J=2.8), 3.78(\mathrm{~s}, 3 \mathrm{H}), 2.6-2.7(\mathrm{~m}, 2 \mathrm{H}), 1.24(\mathrm{t}, 3 \mathrm{H}, J=7.6) . \delta_{\mathrm{C}}(100$ $\left.\mathrm{MHz}, \mathrm{CDCl}_{3}\right) \delta: 159.4,145.7,131.8,128.2,125.8,119.8,117.3$, 108.8, 103.7, 93.2, 93.0, 55.8, 29.1, 15.5, (missing one peak due to overlapping). Mp: $96-98{ }^{\circ} \mathrm{C}$. HRMS (EI) $m / z$ for $\mathrm{C}_{17} \mathrm{H}_{14} \mathrm{I}_{2} \mathrm{O}$ $[\mathrm{M}]^{+}$: calcd 487.9134; found, 487.9121 .

\section{Synthesis of 1,2-diiodo-5-methoxy-3-((4-(trifluoromethyl) phenyl)ethynyl)benzene $\left(\mathbf{1 4}_{\mathrm{A}}\right)$}

The title compound was synthesized using the general procedure and isolated in $\mathbf{3 6 \%}$ yield as white solid after flash chromatography. IR (cast film, $\mathrm{cm}^{-1}$ ) 3102, 3075, 3005, 2209, 1597, $1578,1310,1125,993,867,631,523 . \delta_{\mathrm{H}}\left(400 \mathrm{MHz} \mathrm{CDCl}_{3}\right) \delta: 7.68$ $(\mathrm{d}, 2 \mathrm{H}, J=8.2 \mathrm{~Hz}), 7.62(\mathrm{~d}, 2 \mathrm{H}, J=8.4 \mathrm{~Hz}), 7.44(\mathrm{~d}, 1 \mathrm{H}, J=2.9$ $\mathrm{Hz}), 7.06(\mathrm{~d}, 1 \mathrm{H}, J=2.8 \mathrm{~Hz}), 3.8(\mathrm{~s}, 3 \mathrm{H}) . \delta_{\mathrm{C}}\left(100 \mathrm{MHz}, \mathrm{CDCl}_{3}\right) \delta$ : $159.5,132.1,130.9,130.8\left(\mathrm{q}, J_{\mathrm{C}-\mathrm{F}}=30 \mathrm{~Hz}\right), 126.5,126.4,125.5(\mathrm{q}$, $\left.J_{\mathrm{C}-\mathrm{F}}=4 \mathrm{~Hz}\right), 124.0\left(\mathrm{q}, J_{\mathrm{C}-\mathrm{F}}=270 \mathrm{~Hz}\right), 117.7,109.1,103.7,95.5$, 91.1, 55.9. Mp: $92-94{ }^{\circ} \mathrm{C}$. HRMS (EI) $m / z$ for $\mathrm{C}_{16} \mathrm{H}_{9} \mathrm{~F}_{3} \mathrm{I}_{2} \mathrm{O}[\mathrm{M}]^{+}$: calcd 527.8695; found, 527.8682 .

\section{Synthesis of 1-((4-fluorophenyl)ethynyl)-2,3-diiodo-5- methoxybenzene $\left(15_{\mathrm{A}}\right)$}

The title compound was synthesized using the general procedure and isolated in $\mathbf{2 7 \%}$ yield as white solid after flash chromatography. IR (cast film, $\mathrm{cm}^{-1}$ ) 3104, 3078, 2204, 1608, 1599, $1359,1146,984,873,749,653 . \delta_{\mathrm{H}}\left(400 \mathrm{MHz}, \mathrm{CDCl}_{3}\right) \delta: 7.54-7.58$ $(\mathrm{m}, 2 \mathrm{H}), 7.41(\mathrm{~d}, 1 \mathrm{H}, J=2.9 \mathrm{~Hz}), 7.07(\mathrm{t}, 2 \mathrm{H}, J=8.7 \mathrm{~Hz}), 7.03(\mathrm{~d}$, $1 \mathrm{H}, J=2.8 \mathrm{~Hz}), 3.78(\mathrm{~s}, 3 \mathrm{H}) . \delta_{\mathrm{C}}\left(100 \mathrm{MHz}, \mathrm{CDCl}_{3}\right) \delta: 163.0(\mathrm{~d}$, $\left.J_{\mathrm{C}-\mathrm{F}}=149 \mathrm{~Hz}\right), 159.4,133.8,133.8\left(\mathrm{~d}, J_{\mathrm{C}-\mathrm{F}}=9 \mathrm{~Hz}\right), 125.9,118.8$ $\left(\mathrm{d}, J_{\mathrm{C}-\mathrm{F}}=4 \mathrm{~Hz}\right), 117.4,115.9\left(\mathrm{~d}, J_{\mathrm{C}-\mathrm{F}}=21 \mathrm{~Hz}\right), 108.9,103.6,93.1$, 91.7, 55.8. Mp: $70-72{ }^{\circ} \mathrm{C}$. HRMS (EI) $m / z$ for $\mathrm{C}_{15} \mathrm{H}_{9} \mathrm{FI}_{2} \mathrm{O}[\mathrm{M}]^{+}$: calcd 477.8727; found, 477.8713 .

\section{Synthesis of 4-((2,3-diiodo-5-methoxyphenyl)ethynyl)-1,1' biphenyl $\left(16_{\mathrm{A}}\right)$}

The title compound was synthesized using the general procedure and isolated in $\mathbf{5 1 \%}$ yield white solid after flash chromatography. IR (cast film, $\mathrm{cm}^{-1}$ ) 3145, 3048, 2213, 1609, 1588, $1189,1077,961,632 . \delta_{\mathrm{H}}\left(400 \mathrm{MHz}, \mathrm{CDCl}_{3}\right) \delta: 7.55-7.70(\mathrm{~m}, 5 \mathrm{H})$, $7.47\left(\mathrm{dd}, 2 \mathrm{H}, J^{1}=7.3 \mathrm{~Hz}, J^{2}=7.8 \mathrm{~Hz}\right), 7.42(\mathrm{~d}, 1 \mathrm{H}, J=2.8 \mathrm{~Hz})$, 
$7.37\left(\mathrm{dd}, 2 \mathrm{H}, J^{1}=7.4 \mathrm{~Hz}, J^{2}=7.2 \mathrm{~Hz}\right), 7.07(\mathrm{~d}, 1 \mathrm{H}, J=2.8), 3.80$ $(\mathrm{s}, 3 \mathrm{H}) . \delta_{\mathrm{C}}\left(100 \mathrm{MHz}, \mathrm{CDCl}_{3}\right) \delta: 159.5,141.8,140.4,132.3,131.7$, 129.1, 127.9, 127.3, 127.2, 125.9, 121.5, 117.4, 108.9, 103.8, 94.1, 92.8, 55.9. Mp: $85-87{ }^{\circ} \mathrm{C}$. HRMS (EI) $m / z$ for $\mathrm{C}_{21} \mathrm{H}_{14} \mathrm{I}_{2} \mathrm{O}[\mathrm{M}]^{+}$: calcd 535.9134; found, 535.9119.

\section{Synthesis of 5-chloro-1,2-diiodo-3-(phenylethynyl)benzene $\left(17_{A}\right)$}

The title compound was synthesized using the general procedure and isolated in $\mathbf{4 2} \%$ yield as white solid after flash chromatography. IR (cast film, $\mathrm{cm}^{-1}$ ) 3104, 3086, 2207, 1602, 1071, 943, 827, 634. $\delta_{\mathrm{H}}\left(400 \mathrm{MHz}, \mathrm{CDCl}_{3}\right) \delta: 7.79(\mathrm{~d}, 1 \mathrm{H}, J=2.4 \mathrm{~Hz})$, 7.57-7.59 (m, 2H), $7.46(\mathrm{~d}, 1 \mathrm{H}, J=2.3 \mathrm{~Hz}), 7.38-7.39(\mathrm{~m}, 3 \mathrm{H}) . \delta_{\mathrm{C}}$ $\left(100 \mathrm{MHz} \mathrm{CDCl}_{3}\right) \delta: 138.3,134.6,132.6,131.9,131.2,129.4$, 128.6, 122.3, 112.5, 109.2, 94.3, 92.5. Mp: 90-92 ${ }^{\circ} \mathrm{C}$. HRMS (EI) $m / z$ for $\mathrm{C}_{14} \mathrm{H}_{7} \mathrm{ClI}_{2}[\mathrm{M}]^{+}$: calcd 463.8326; found, 463.8323 .

\section{Synthesis of 5-chloro-1-((4-ethylphenyl)ethynyl)-2,3-diiodo benzene $\left(18_{\mathrm{A}}\right)$}

The title compound was synthesized using the general procedure and isolated in $\mathbf{3 4 \%}$ yield as white solid after flash chromatography. IR (cast film, $\mathrm{cm}^{-1}$ ): 3104, 3089, 3018, 2212, 1579, 1542, 928, 813, 742, 642. $\delta_{\mathrm{H}}\left(400 \mathrm{MHz}, \mathrm{CDCl}_{3}\right) \delta: 7.78(\mathrm{~d}, 1 \mathrm{H}$, $J=2.2 \mathrm{~Hz}$ ), 7.49 (d, 2H, $J=8.0 \mathrm{~Hz}), 7.45(\mathrm{~d}, 1 \mathrm{H}, J=2.2 \mathrm{~Hz}), 7.21$ $(\mathrm{d}, 2 \mathrm{H}, J=7.9 \mathrm{~Hz}), 2.67$ (q, 2H, $J=7.5 \mathrm{~Hz}), 1.25(\mathrm{t}, 3 \mathrm{H}, J=7.6$ $\mathrm{Hz}) . \delta_{\mathrm{C}}\left(100 \mathrm{MHz}, \mathrm{CDCl}_{3}\right) \delta: 146.0,138.0,134.5,132.8,131.9$, 131.0, 128.2, 119.4, 112.5, 109.2, 94.6, 92.0, 29.1, 15.5. Mp: 87$89{ }^{\circ} \mathrm{C}$. HRMS (EI) $\mathrm{m} / z$ for $\mathrm{C}_{16} \mathrm{H}_{11} \mathrm{ClI}_{2}[\mathrm{M}]^{+}$: calcd 491.8639; found, 491.8632 .

\section{Synthesis of 5-chloro-1,2-diiodo-3-((4-methoxyphenyl)ethynyl)} benzene $\left(19_{A}\right)$

The title compound was synthesized using the general procedure and isolated in $\mathbf{4 4 \%}$ yield as white solid after flash chromatography. IR (cast film, $\mathrm{cm}^{1}$ ): 3121, 3049, 2209, 1613, 1597, $1310,1149,976,842,742,619 . \delta_{\mathrm{H}}\left(400 \mathrm{MHz} \mathrm{CDCl}_{3}\right) \delta: 7.76(\mathrm{~d}$, $1 \mathrm{H}, J=2.2 \mathrm{~Hz}), 7.51(\mathrm{~d}, 2 \mathrm{H}, J=8.7 \mathrm{~Hz}), 7.43(\mathrm{~d}, 1 \mathrm{H}, J=2.2 \mathrm{~Hz})$, $6.89(\mathrm{~d}, 2 \mathrm{H}, J=8.8 \mathrm{~Hz}), 3.48(\mathrm{~s}, 3 \mathrm{H}) . \delta_{\mathrm{C}}\left(100 \mathrm{MHz}, \mathrm{CDCl}_{3}\right) \delta$ : $160.6,137.9,134.5,133.6,133.5,132.9,130.9,114.3,112.3$, 109.1, 94.6, 91.6, 55.5. Mp: $112-114{ }^{\circ} \mathrm{C}$. HRMS (EI) $\mathrm{m} / z$ for $\mathrm{C}_{15} \mathrm{H}_{9} \mathrm{ClI}_{2} \mathrm{O}[\mathrm{M}]^{+}$: calcd 493.8431; found, 493.8425 .

\section{Synthesis of 5-chloro-1,2-diiodo-3-((4-(trifluoromethyl)phenyl) ethynyl)benzene $\left(20_{A}\right)$}

The title compound was synthesized using the general procedure and isolated in $\mathbf{3 1 \%}$ yield as white solid after flash chromatography. IR (cast film, $\mathrm{cm}^{-1}$ ) 3107, 3088, 3012, 2196, 1612, 1579, 1012, 983, 867, 764, 642, 521. $\delta_{\mathrm{H}}\left(400 \mathrm{MHz}, \mathrm{CDCl}_{3}\right) \delta: 7.81$ $(\mathrm{d}, 1 \mathrm{H}, J=2.4 \mathrm{~Hz}), 7.60-7.70(\mathrm{~m}, 4 \mathrm{H}), 7.46(\mathrm{~d}, 1 \mathrm{H}, J=2.4 \mathrm{~Hz}) . \delta_{\mathrm{C}}$ $\left(100 \mathrm{MHz}, \mathrm{CDCl}_{3}\right) \delta: 138.8,134.7,133.0,132.1,131.8,131.4$, $131.0(\mathrm{q}, J=32 \mathrm{~Hz}), 125.6(\mathrm{q}, J=4 \mathrm{~Hz}), 123.9\left(\mathrm{q}, J_{\mathrm{C}-\mathrm{F}}=271 \mathrm{~Hz}\right)$, 112.6, 109.5, 94.4, 92.4. Mp: $116-118{ }^{\circ} \mathrm{C}$. HRMS (EI) $\mathrm{m} / z$ for $\mathrm{C}_{15} \mathrm{H}_{6} \mathrm{ClF}_{3} \mathrm{I}_{2}[\mathrm{M}]^{+}$: calcd 531.8199; found, 531.8188 .

\section{Synthesis of 5-bromo-1-((4-ethylphenyl)ethynyl)-2,3-} diiodobenzene $\left(21_{A}\right)$

The title compound was synthesized using the general procedure and isolated in $\mathbf{8 5 \%}$ yield as colorless oil after flash chromatography. IR (cast film, $\mathrm{cm}^{1}$ ): 3142, 3048, 3013, 2201, 1592, 943, 841, 746, 529. $\delta_{\mathrm{H}}\left(400 \mathrm{MHz}, \mathrm{CDCl}_{3}\right) \delta: 7.93(\mathrm{~d}, 1 \mathrm{H}, J=2.2$ $\mathrm{Hz}), 7.67(\mathrm{~d}, 1 \mathrm{H}, J=2.2 \mathrm{~Hz}), 7.47(\mathrm{~d}, 2 \mathrm{H}, J=8.1 \mathrm{~Hz}), 7.20(\mathrm{~d}, 2 \mathrm{H}$, $J=8.0 \mathrm{~Hz}), 2.68(\mathrm{q}, 2 \mathrm{H}, J=7.6 \mathrm{~Hz}), 1.25(\mathrm{t}, 3 \mathrm{H}, J=7.6 \mathrm{~Hz}) . \delta_{\mathrm{C}}$ $\left(100 \mathrm{MHz}, \mathrm{CDCl}_{3}\right) \delta: 146.0,141.6,135.4,132.0,128.2,125.5$, 120.1, 119.4, 99.3, 96.7, 85.0, 29.1, 15.5, (missing one peak due to overlapping). HRMS (EI) $m / z$ for $\mathrm{C}_{16} \mathrm{H}_{11} \mathrm{BrI}_{2}[\mathrm{M}]^{+}$: calcd 535.8133; found, 535.8128 .

\section{Synthesis of 5-bromo-1-((3-fluorophenyl)ethynyl)-2,3-diiodo benzene $\left(22_{\mathrm{A}}\right)$}

The title compound was synthesized using the general procedure and isolated in $\mathbf{4 4 \%}$ yield as white solid after flash chromatography. IR (cast film, $\mathrm{cm}^{-1}$ ) 3097, 3048, 2214, 1598, 948, 812, 794, 653. $\delta_{\mathrm{H}}\left(400 \mathrm{MHz}, \mathrm{CDCl}_{3}\right) \delta: 7.95(\mathrm{~d}, 1 \mathrm{H}, J=2.2 \mathrm{~Hz})$, $7.66(\mathrm{~d}, 1 \mathrm{H}, J=2.2 \mathrm{~Hz}), 7.32-7.34(\mathrm{~m}, 2 \mathrm{H}), 7.23(\mathrm{~d}, 1 \mathrm{H}, J=9.2$ $\mathrm{Hz}), \quad 7.10-7.11(\mathrm{~m}, 1 \mathrm{H}) . \quad \delta_{\mathrm{C}}\left(100 \mathrm{MHz}, \mathrm{CDCl}_{3}\right) \delta: 161.5$ $\left(\mathrm{d}, J_{\mathrm{C}-\mathrm{F}}=246 \mathrm{~Hz}\right), 142.2,139.3,135.6,130.2\left(\mathrm{~d}, J_{\mathrm{C}-\mathrm{F}}=8 \mathrm{~Hz}\right)$, $129.9\left(\mathrm{~d}, J_{\mathrm{C}-\mathrm{F}}=3 \mathrm{~Hz}\right), 124.8,124.0\left(\mathrm{~d}, J_{\mathrm{C}-\mathrm{F}}=10 \mathrm{~Hz}\right), 120.2,118.8$ $\left(\mathrm{d}, J_{\mathrm{C}-\mathrm{F}}=22 \mathrm{~Hz}\right), 116.8\left(\mathrm{~d}, J_{\mathrm{C}-\mathrm{F}}=22 \mathrm{~Hz}\right), 99.4,94.8\left(\mathrm{~d}, J_{\mathrm{C}-\mathrm{F}}=3\right.$ $\mathrm{Hz}$ ), 86.2. Mp: $68-70{ }^{\circ} \mathrm{C}$ HRMS (EI) $m / z$ for $\mathrm{C}_{14} \mathrm{H}_{6} \mathrm{BrFI}_{2}[\mathrm{M}]^{+}$: calcd 525.7726; found, 525.7719.

\section{Synthesis of 5-fluoro-1,2-diiodo-3-((4-methoxyphenyl)ethynyl) benzene $\left(23_{\mathrm{A}}\right)$}

The title compound was synthesized using the general procedure and isolated in $\mathbf{7 4 \%}$ yield as white solid after flash chromatography. IR (cast film, $\mathrm{cm}^{-1}$ ) 3102, 3042, 2191, 1608, 1597, 1023, 894, 742, 691. $\delta_{\mathrm{H}}\left(400 \mathrm{MHz}, \mathrm{CDCl}_{3}\right) \delta: 7.51-7.57(\mathrm{~m}, 3 \mathrm{H})$, $7.20\left(\mathrm{dd}, 1 \mathrm{H}, J^{1}=2.7 \mathrm{~Hz}, J^{2}=8.6 \mathrm{~Hz}\right), 6.90(\mathrm{~d}, 2 \mathrm{H}, J=8.6 \mathrm{~Hz})$, $3.84(\mathrm{~s}, 3 \mathrm{H}) . \delta_{\mathrm{C}}\left(100 \mathrm{MHz}, \mathrm{CDCl}_{3}\right) \delta: 161.6\left(\mathrm{~d}, J_{\mathrm{C}-\mathrm{F}}=251 \mathrm{~Hz}\right)$, $160.6,133.5,132.9\left(\mathrm{~d}, J_{\mathrm{C}-\mathrm{F}}=10 \mathrm{~Hz}\right), 130.9,126.3\left(\mathrm{~d}, J_{\mathrm{C}-\mathrm{F}}=24\right.$ $\mathrm{Hz}), 118.4\left(\mathrm{~d}, J_{\mathrm{C}-\mathrm{F}}=23 \mathrm{~Hz}\right), 108.7\left(\mathrm{~d}, J_{\mathrm{C}-\mathrm{F}}=4 \mathrm{~Hz}\right), 108.6,108.5$, 94.5, $91.8\left(\mathrm{~d}, J_{\mathrm{C}-\mathrm{F}}=3 \mathrm{~Hz}\right), 55.5$. Mp: $87-90^{\circ} \mathrm{C}$. HRMS (EI) $\mathrm{m} / \mathrm{z}$ for $\mathrm{C}_{15} \mathrm{H}_{9} \mathrm{FI}_{2} \mathrm{O}[\mathrm{M}]^{+}$: calcd 477.8727; found, 477.8718 .

\section{Synthesis of 1-((4-chlorophenyl)ethynyl)-5-fluoro-2,3-diiodo benzene $\left(24_{A}\right)$}

The title compound was synthesized using the general procedure and isolated in $\mathbf{4 2 \%}$ yield as white solid after flash chromatography. IR (cast film, $\mathrm{cm}^{-1}$ ) 3089, 3041, 2201, 1597, 1524, 1016, 927, 813, 691. $\delta_{\mathrm{H}}\left(400 \mathrm{MHz}, \mathrm{CDCl}_{3}\right) \delta: 7.57(\mathrm{dd}, 1 \mathrm{H}$, $\left.J^{1}=7.7 \mathrm{~Hz}, J^{2}=2.4 \mathrm{~Hz}\right), 7.48(\mathrm{~d}, 2 \mathrm{H}, J=8.3 \mathrm{~Hz}), 7.34(\mathrm{~d}, 2 \mathrm{H}, J=$ $8.2 \mathrm{~Hz}), 7.20\left(\mathrm{dd}, 1 \mathrm{H}, J^{1}=8.6 \mathrm{~Hz}, J^{2}=2.4 \mathrm{~Hz}\right) . \delta_{\mathrm{C}}(100 \mathrm{MHz}$, $\left.\mathrm{CDCl}_{3}\right) \delta: 161.5\left(\mathrm{~d}, J_{\mathrm{C}-\mathrm{F}}=252 \mathrm{~Hz}\right), 135.5,133.1,132.1\left(\mathrm{~d}, J_{\mathrm{C}-\mathrm{F}}=\right.$ $10 \mathrm{~Hz}), 129.0,126.8\left(\mathrm{~d}, J_{\mathrm{C}-\mathrm{F}}=24 \mathrm{~Hz}\right), 120.8,118.8\left(\mathrm{~d}, J_{\mathrm{C}-\mathrm{F}}=23\right.$ $\mathrm{Hz}), 108.9\left(\mathrm{~d}, J_{\mathrm{C}-\mathrm{F}}=4 \mathrm{~Hz}\right), 108.8\left(\mathrm{~d}, J_{\mathrm{C}-\mathrm{F}}=8 \mathrm{~Hz}\right), 93.5\left(\mathrm{~d}, J_{\mathrm{C}-\mathrm{F}}=3\right.$ $\mathrm{Hz}$ ), 92.9. Mp: $113-114{ }^{\circ} \mathrm{C}$. HRMS (EI) $m / z$ for $\mathrm{C}_{14} \mathrm{H}_{6} \mathrm{ClFI}_{2}[\mathrm{M}]^{+}$: calcd 481.8231; found, 481.8228 . 
Synthesis of methyl 3,4-diiodo-5-((4-methoxyphenyl)ethynyl) benzoate $\left(25_{\mathrm{A}}\right)$

The title compound was synthesized using the general procedure and isolated in $\mathbf{3 3 \%}$ yield as white solid after flash chromatography. IR (cast film, $\mathrm{cm}^{-1}$ ) 3104, 3085, 2195, 1765, 1604, $1586,1415,1204,1112,876,743 . \delta_{\mathrm{H}}\left(400 \mathrm{MHz}, \mathrm{CDCl}_{3}\right) \delta: 8.37$ (d, $1 \mathrm{H}, J=1.8 \mathrm{~Hz}), 8.05(\mathrm{~d}, 1 \mathrm{H}, J=1.8 \mathrm{~Hz}), 7.52(\mathrm{~d}, 2 \mathrm{H}, J=8.8 \mathrm{~Hz})$, $6.90(\mathrm{~d}, 2 \mathrm{H}, J=8.7 \mathrm{~Hz}), 3.92(\mathrm{~s}, 3 \mathrm{H}), 3.84(\mathrm{~s}, 3 \mathrm{H}) . \delta_{\mathrm{C}}(100 \mathrm{MHz}$, $\mathrm{CDCl}_{3}$ ) $\delta: 165.1,160.5,138.7,133.4,132.5,131.5,131.1,120.6$, 114.5, 114.3, 108.9, 94.4, 91.9, 55.5, 52.8. Mp: $173-175^{\circ} \mathrm{C} . \mathrm{HRMS}$ (EI) $\mathrm{m} / z$ for $\mathrm{C}_{17} \mathrm{H}_{12} \mathrm{I}_{2} \mathrm{O}_{3}[\mathrm{M}]^{+}$: calcd 517.8876; found, 517.8874 .

\section{Synthesis of 1-chloro-3-((4-chlorophenyl)ethynyl)-2- iodobenzene $\left(26_{A}\right)$}

The title compound was synthesized using the general procedure and isolated in $\mathbf{4 5 \%}$ yield as white solid after flash chromatography. IR (cast film, $\mathrm{cm}^{-1}$ ) 3078, 3024, 2208, 1601, 1598, 1107, 867, 523. $\delta_{\mathrm{H}}\left(400 \mathrm{MHz}, \mathrm{CDCl}_{3}\right) \delta: 7.52(\mathrm{~d}, 2 \mathrm{H}, J=8.4 \mathrm{~Hz})$, $7.34-7.40(\mathrm{~m}, 4 \mathrm{H}), 7.26(\mathrm{dd}, 1 \mathrm{H}, J=7.7 \mathrm{~Hz}, J=7.9 \mathrm{~Hz}) . \delta_{\mathrm{C}}(100$ $\left.\mathrm{MHz}, \mathrm{CDCl}_{3}\right) \delta: 139.8,135.2,133.9,133.0,132.5,130.4,129.0$, 128.9, 121.3, 105.5, 93.0, 92.5. Mp: 90-92 ${ }^{\circ} \mathrm{C}$. HRMS (EI) $m / z$ for $\mathrm{C}_{14} \mathrm{H}_{7} \mathrm{Cl}_{2} \mathrm{I}[\mathrm{M}]^{+}$: calcd 371.8969; found, 371.8960 .

\section{Synthesis of 1-bromo-2-iodo-3-((4-methoxyphenyl)ethynyl) benzene $\left(27_{A}\right)$}

The title compound was synthesized using the general procedure and isolated in $\mathbf{6 2} \%$ yield as white solid after flash chromatography. IR (cast film, $\mathrm{cm}^{-1}$ ) 3097, 3021, 2207, 1578, 1543, $1204,1079,894,742 . \delta_{\mathrm{H}}\left(400 \mathrm{MHz}, \mathrm{CDCl}_{3}\right) \delta: 7.53(\mathrm{~d}, 3 \mathrm{H}, J=8.2$ $\mathrm{Hz}), 7.41$ (d, $1 \mathrm{H}, J=7.6 \mathrm{~Hz}), 7.17\left(\mathrm{dd}, 1 \mathrm{H}, J^{1}=7.9, J^{2}=7.8 \mathrm{~Hz}\right)$, $6.90(\mathrm{~d}, 2 \mathrm{H}, J=8.3 \mathrm{~Hz}), 3.84(\mathrm{~s}, 3 \mathrm{H}) . \delta_{\mathrm{C}}\left(100 \mathrm{MHz}, \mathrm{CDCl}_{3}\right) \delta$ : 160.3 , 133.3, 133.2, 131.8, 130.7, 130.5, 129.1, 114.8, 114.3, 108.3, 93.9, 91.6, 55.5. Mp: 53-55 ${ }^{\circ} \mathrm{C}$. HRMS (EI) $m / z$ for $\mathrm{C}_{15} \mathrm{H}_{10} \mathrm{BrIO}[\mathrm{M}]^{+}$: calcd 411.8960; found, 411.8954 .

\section{General procedure for one-pot double Sonogashira cross-} coupling reactions of 5-substituted-1,2,3-triiodobenzenes

A flame-dried Schlenk flask was charged with 5-substituted1,2,3-triiodobenzene ( $0.65 \mathrm{mmol}, 0.08 \mathrm{M}, 1.0$ equiv.), aryl acetylene (1.0 equiv.), $\mathrm{Cs}_{2} \mathrm{CO}_{3}$ (7.0 equiv.) in $8.0 \mathrm{~mL}$ dry toluene under argon. The mixture was stirred at room temperature for $20 \mathrm{~min}$. Tetrakis(triphenylphosphine)palladium (0) (10 mol\%) and copper iodide (20 mol\%) were added, capped with septum, carefully degassed with argon, and the reaction flask was wrapped with aluminum foil and stirred at room temperature for $24 \mathrm{~h}$. Aryl acetylene (1.0 equiv.) and $\mathrm{Cs}_{2} \mathrm{CO}_{3}$ (7.0 equiv.) were added to the mixture, carefully degassed with argon, wrapped with aluminum foil and stirred at room temperature for another $24 \mathrm{~h}$. The reaction mixture was diluted with EtOAc and filtered over Celite $545 \AA$. Distilled water $(100 \mathrm{~mL})$ was added and extracted with EtOAc $(2 \times 50 \mathrm{~mL})$. The organic layers were combined washed with brine, dried with anhyd. $\mathrm{Na}_{2} \mathrm{SO}_{4}$, filtered and evaporated under reduced pressure. The crude product was purified by flash chromatography ( $100 \%$ hexane) to yield the pure desired product.
Synthesis of 2-iodo-5-methoxy-1-((4-methoxyphenyl)ethynyl)3-((4-(trifluoromethyl)phenyl)ethynyl)benzene $\left(28_{\mathrm{A}}\right)$

The title compound was synthesized using the one-pot general procedure and isolated in $\mathbf{4 8 \%}$ yield as pale yellow oil after flash chromatography. IR (cast film, $\mathrm{cm}^{-1}$ ) 3124, 3086, 3006, 2203, 1601, 1583, 1204, 1139, 976, 867, 647. $\delta_{\mathrm{H}}\left(400 \mathrm{MHz}, \mathrm{CDCl}_{3}\right) \delta$ : $7.71(\mathrm{~d}, 2 \mathrm{H}, J=8.1 \mathrm{~Hz}), 7.62(\mathrm{~d}, 2 \mathrm{H}, J=8.1 \mathrm{~Hz}), 7.56(\mathrm{~d}, 2 \mathrm{H}$, $J=8.5 \mathrm{~Hz}), 7.06(\mathrm{~d}, 1 \mathrm{H}, J=2.7 \mathrm{~Hz}), 7.04(\mathrm{~d}, 1 \mathrm{H}, J=2.8 \mathrm{~Hz}), 6.90$ $(\mathrm{d}, 2 \mathrm{H}, J=8.5 \mathrm{~Hz}), 3.84(\mathrm{~s}, 3 \mathrm{H}), 3.82(\mathrm{~s}, 3 \mathrm{H}) . \delta_{\mathrm{C}}\left(100 \mathrm{MHz}, \mathrm{CDCl}_{3}\right)$ $\delta: 160.3,159.2,133.4,131.5\left(\mathrm{q}, J_{\mathrm{C}-\mathrm{F}}=134 \mathrm{~Hz}\right), 132.0,130.5$ $\left(\mathrm{q}, J_{\mathrm{C}-\mathrm{F}}=33 \mathrm{~Hz}\right), 126.8,125.5,125.4\left(\mathrm{q}, J_{\mathrm{C}-\mathrm{F}}=4 \mathrm{~Hz}\right), 122.7$, 118.2, 118.0, 114.9, 114.3, 97.0, 94.3, 93.7, 91.3, 90.8, 55.8, 55.5. HRMS (EI) $m / z$ for $\mathrm{C}_{25} \mathrm{H}_{16} \mathrm{~F}_{3} \mathrm{IO}_{2}[\mathrm{M}]^{+}$: calcd 532.0147; found, 532.0133 .

\section{Synthesis of 5-bromo-1-((4-ethylphenyl)ethynyl)-3-((3-fluoro phenyl)ethynyl)-2-iodobenzene (29A)}

The title compound was synthesized using the one-pot general procedure and isolated in $\mathbf{3 4 \%}$ yield as white solid after flash chromatography. IR (cast film, $\mathrm{cm}^{-1}$ ) 3125, 3073, 3041, 2201, $1623,1579,1042,941,837,622 . \delta_{\mathrm{H}}\left(400 \mathrm{MHz}, \mathrm{CDCl}_{3}\right) \delta: 7.64(\mathrm{dd}$, $\left.2 \mathrm{H}, J^{1}=10.9 \mathrm{~Hz}, J^{2}=2.1 \mathrm{~Hz}\right), 7.50(\mathrm{~d}, 2 \mathrm{H}, J=7.9 \mathrm{~Hz}), 7.28-7.36$ $(\mathrm{m}, 3 \mathrm{H}), 7.21$ (d, 2H,J = 7.8 Hz), 7.00-7.15 (m, 1H), 2.67 (q, 2H, $J=7.6 \mathrm{~Hz}), 1.26(\mathrm{~m}, 3 \mathrm{H}) . \delta_{\mathrm{C}}\left(100 \mathrm{MHz}, \mathrm{CDCl}_{3}\right) \delta: 162.5\left(\mathrm{~d}, J_{\mathrm{C}-\mathrm{F}}=\right.$ $245 \mathrm{~Hz}), 136.6,135.4,135.0,132.0,130.2\left(\mathrm{~d}, J_{\mathrm{C}-\mathrm{F}}=8 \mathrm{~Hz}\right), 128.2$, $127.9\left(\mathrm{~d}, J_{\mathrm{C}-\mathrm{F}}=2 \mathrm{~Hz}\right), 126.0,125.1,124.3\left(\mathrm{~d}, J_{\mathrm{C}-\mathrm{F}}=9 \mathrm{~Hz}\right), 119.5$, $119.4,118.7\left(\mathrm{~d}, J_{\mathrm{C}-\mathrm{F}}=23 \mathrm{~Hz}\right), 116.6\left(\mathrm{~d}, J_{\mathrm{C}-\mathrm{F}}=21 \mathrm{~Hz}\right), 96.8,94.6$, 85.8, 84.3, 29.1, 15.5, (missing one peak due to overlapping). Mp: 83-85 ${ }^{\circ} \mathrm{C}$. HRMS (EI) $\mathrm{m} / z$ for $\mathrm{C}_{24} \mathrm{H}_{15} \mathrm{BrFI}[\mathrm{M}]^{+}$: calcd 527.9386; found, 527.9382.

Synthesis of 4,4'-((2-iodo-1,3-phenylene)bis(ethyne-2,1-diyl)) bis(methoxybenzene) $\left(30_{\mathrm{A}}\right)$

The title compound was synthesized using the one-pot general procedure and isolated in $\mathbf{5 7 \%}$ yield as pale yellow oil after flash chromatography. IR (cast film, $\mathrm{cm}^{-1}$ ) 3124, 3082, 3012, 2214, 1624, 1602, 967, 962, 841, 723. $\delta_{\mathrm{H}}\left(400 \mathrm{MHz}, \mathrm{CDCl}_{3}\right) \delta: 7.55(\mathrm{~d}$, $4 \mathrm{H}, J=8.7 \mathrm{~Hz}), 7.40(\mathrm{~d}, 2 \mathrm{H}, J=7.5 \mathrm{~Hz}), 7.28(\mathrm{~d}, 1 \mathrm{H}, J=8.0 \mathrm{~Hz})$, $6.90(\mathrm{~d}, 4 \mathrm{H}, J=8.7 \mathrm{~Hz}), 3.8(\mathrm{~s}, 6 \mathrm{H}) . \delta_{\mathrm{C}}\left(100 \mathrm{MHz} \mathrm{CDCl}_{3}\right) \delta: 160.2$, 133.3, 131.5, 131.2, 127.8, 115.2, 114.3, 107.7, 93.5, 91.2, 55.5. HRMS (EI) $m / z$ for $\mathrm{C}_{24} \mathrm{H}_{17} \mathrm{IO}_{2}[\mathrm{M}]^{+}$: calcd 464.0273; found, 464.0269 .

Synthesis of 4,4'-((2-iodo-5-methoxy-1,3-phenylene)bis(ethyne2,1-diyl))bis(methoxybenzene) $\left(31_{A}\right)$

The title compound was synthesized using the one-pot general procedure and isolated in 69\% yield as colorless oil after flash chromatography. IR (cast film, $\mathrm{cm}^{-1}$ ) 3124, 3075, 3042, 2198, $1614,1587,1345,1207,1184,986,748,625 . \delta_{\mathrm{H}}\left(400 \mathrm{MHz}, \mathrm{CDCl}_{3}\right)$ $\delta: 7.55(\mathrm{~d}, 4 \mathrm{H}, J=8.6 \mathrm{~Hz}), 7.02(\mathrm{~s}, 2 \mathrm{H}), 6.90(\mathrm{~d}, 4 \mathrm{H}, J=8.6 \mathrm{~Hz})$, $3.84(\mathrm{~s}, 6 \mathrm{H}), 3.82(\mathrm{~s}, 3 \mathrm{H}) . \delta_{\mathrm{C}}\left(100 \mathrm{MHz}, \mathrm{CDCl}_{3}\right) \delta: 160.2,159.2$, 133.4, 131.9, 117.5, 115.1, 114.3, 96.9, 93.3, 91.1, 55.8, 55.5. HRMS (EI) $\mathrm{m} / \mathrm{z}$ for $\mathrm{C}_{25} \mathrm{H}_{19} \mathrm{IO}_{3}[\mathrm{M}]^{+}$: calcd 494.0379; found, 494.0371. 
Synthesis of 3,3'-((5-bromo-2-iodo-1,3-phenylene)bis(ethyne2,1-diyl))bis(fluorobenzene) $\left(32_{\mathrm{A}}\right)$

The title compound was synthesized using the one-pot general procedure and isolated in $\mathbf{5 5 \%}$ yield as white solid after flash chromatography. IR (cast film, $\mathrm{cm}^{-1}$ ) 3124, 3057, 2195, 1604, $1578,684,742,628 . \delta_{\mathrm{H}}\left(400 \mathrm{MHz}, \mathrm{CDCl}_{3}\right) \delta: 7.66(\mathrm{~s}, 2 \mathrm{H}), 7.33-$ $7.36(\mathrm{~m}, 4 \mathrm{H}), 7.22-7.30(\mathrm{~m}, 2 \mathrm{H}), 7.07-7.12(\mathrm{~m}, 2 \mathrm{H}) . \delta_{\mathrm{C}}(100 \mathrm{MHz}$, $\left.\mathrm{CDCl}_{3}\right) \delta: 162.6\left(\mathrm{~d}, J_{\mathrm{C}-\mathrm{F}}=245 \mathrm{~Hz}\right), 136.8,135.5,130.3\left(\mathrm{~d}, J_{\mathrm{C}-\mathrm{F}}=8\right.$ $\mathrm{Hz}), 127.9\left(\mathrm{~d}, J_{\mathrm{C}-\mathrm{F}}=2 \mathrm{~Hz}\right), 125.4,124.2\left(\mathrm{~d}, J_{\mathrm{C}-\mathrm{F}}=9 \mathrm{~Hz}\right), 119.5$, $118.8\left(\mathrm{~d}, J_{\mathrm{C}-\mathrm{F}}=22 \mathrm{~Hz}\right), 116.7\left(\mathrm{~d}, J_{\mathrm{C}-\mathrm{F}}=21 \mathrm{~Hz}\right), 94.9\left(\mathrm{~d}, J_{\mathrm{C}-\mathrm{F}}=3\right.$ $\mathrm{Hz}$ ), 85.6. Mp: $122-124{ }^{\circ} \mathrm{C}$. HRMS (EI) $m / z$ for $\mathrm{C}_{22} \mathrm{H}_{10} \mathrm{BrF}_{2} \mathrm{I}[\mathrm{M}]^{+}$: calcd 517.8979; found, 517.8975.

\section{Synthesis of 4,4'-((5-bromo-2-iodo-1,3-phenylene)bis(ethyne- 2,1-diyl))bis(ethylbenzene) $\left(33_{A}\right)$}

The title compound was synthesized using the one-pot general procedure and isolated in $\mathbf{8 7 \%}$ yield as colorless oil after flash chromatography. IR (cast film, $\mathrm{cm}^{-1}$ ) 3106, 3086, 3015, 2186, $1612,1592,837,467 . \delta_{\mathrm{H}}\left(400 \mathrm{MHz}, \mathrm{CDCl}_{3}\right) \delta: 7.61(\mathrm{~s}, 2 \mathrm{H}), 7.44(\mathrm{~d}$, $4 \mathrm{H}, J=7.8 \mathrm{~Hz}), 7.16-7.21(\mathrm{~m}, 4 \mathrm{H}), 2.60-2.75(\mathrm{~m}, 4 \mathrm{H}), 1.20-1.30$ $(\mathrm{m}, 6 \mathrm{H}) . \delta_{\mathrm{C}}\left(100 \mathrm{MHz}, \mathrm{CDCl}_{3}\right) \delta: 145.5,133.8,132.7,131.9,128.2$, 125.7, 119.9, 91.6, 86.7, 81.7, 29.0, 15.4. HRMS (EI) $\mathrm{m} / z$ for $\mathrm{C}_{26} \mathrm{H}_{20} \mathrm{BrI}[\mathrm{M}]^{+}$: calcd 537.9793; found, 537.9784.

Synthesis of 4,4'-((2-iodo-1,3-phenylene)bis(ethyne-2,1-diyl)) bis ((trifluoromethyl)benzene) $\left(34_{A}\right)$

The title compound was synthesized using the one-pot general procedure and isolated in $72 \%$ yield as white solid after flash chromatography. IR (cast film, $\mathrm{cm}^{-1}$ ) 3108, 3086, 3046, 2216, $1587,1537,976,891,642 . \delta_{\mathrm{H}}\left(400 \mathrm{MHz}, \mathrm{CDCl}_{3}\right) \delta: 7.72(\mathrm{~d}, 4 \mathrm{H}, J=$ $8.1 \mathrm{~Hz}), 7.64(\mathrm{~d}, 4 \mathrm{H}, J=8.2 \mathrm{~Hz}), 7.50(\mathrm{~d}, 2 \mathrm{H}, J=7.6 \mathrm{~Hz}), 7.36(\mathrm{dd}$, $\left.1 \mathrm{H}, J^{1}=7.9, J^{2}=7.5 \mathrm{~Hz}\right) . \delta_{\mathrm{C}}\left(100 \mathrm{MHz}, \mathrm{CDCl}_{3}\right) \delta: 132.5,132.1$, 130.9, 130.8, 128.1, 126.7, 125.6 (q, $J_{\mathrm{C}-\mathrm{F}}=4 \mathrm{~Hz}$ ), 122.7, 108.1, 94.1, 91.9. Mp: 92-94 ${ }^{\circ} \mathrm{C}$. HRMS (EI) $\mathrm{m} / z$ for $\mathrm{C}_{24} \mathrm{H}_{11} \mathrm{~F}_{6} \mathrm{I}[\mathrm{M}]^{+}$: calcd 539.9810; found, 539.9798.

\section{Synthesis of 4,4'-((5-chloro-2-iodo-1,3-phenylene)bis(ethyne-} 2,1-diyl))bis((trifluoromethyl)benzene) $\left(35_{A}\right)$

The title compound was synthesized using the one-pot general procedure and isolated in $\mathbf{5 5 \%}$ yield as white solid after flash chromatography. IR (cast film, $\mathrm{cm}^{-1}$ ) 3097, 3064, 2207, 1599, $1548,948,816,724,634 . \delta_{\mathrm{H}}\left(400 \mathrm{MHz}, \mathrm{CDCl}_{3}\right) \delta: 7.70(\mathrm{~d}, 4 \mathrm{H}, J=$ $8.3 \mathrm{~Hz}), 7.64(\mathrm{~d}, 4 \mathrm{H}, J=8.9 \mathrm{~Hz}), 7.47(\mathrm{~s}, 2 \mathrm{H}) . \delta_{\mathrm{C}}(100 \mathrm{MHz}$, $\left.\mathrm{CDCl}_{3}\right) \delta: 138.8,134.3,133.0,132.2\left(\mathrm{q}, J_{\mathrm{C}-\mathrm{F}}=34 \mathrm{~Hz}\right), 132.1\left(\mathrm{q}, J_{\mathrm{C}-}\right.$ $\mathrm{F}=3 \mathrm{~Hz}), 131.0\left(\mathrm{q}, J_{\mathrm{C}-\mathrm{F}}=33 \mathrm{~Hz}\right), 125.6\left(\mathrm{q}, J_{\mathrm{C}-\mathrm{F}}=3 \mathrm{~Hz}\right), 124.0(\mathrm{q}$, $J_{\mathrm{C}-\mathrm{F}}=171 \mathrm{~Hz}$ ), 105.5, 93.0, 92.9. Mp: $116-118^{\circ} \mathrm{C}$. HRMS (EI) $\mathrm{m} / \mathrm{z}$ for $\mathrm{C}_{24} \mathrm{H}_{10} \mathrm{ClF}_{6} \mathrm{I}[\mathrm{M}]^{+}$: calcd 573.9420; found, 573.9412 .

\section{Conflicts of interest}

There are no conflicts to declare.

\section{Acknowledgements}

This work was generously funded by Jordan University of Science and Technology (JUST) - Deanship of Research - Jordan (Grant No. 336/2018 for R.M.A.). We thank the department of chemistry at University of Alberta for X-ray crystallographic analysis.

\section{Notes and references}

1 T. P. Selby, N. R. Deprez, A. X. Ding, S. F. McCann, A. D. Satterfield, K. A. Hughes and D. A. Travis, World Patent WO2015191377A1, E. I. du Pont de Nemours and Company, USA, 2015.

2 V. M. Sviripa, W. Zhang, L. M. Kril, A. X. Liu, Y. Yuan, C.-G. Zhan, C. Liu and D. S. Watt, Bioorg. Med. Chem. Lett., 2014, 24, 3638-3640.

3 P. J. Conn, C. W. Lindsley, S. R. Stauffer, C. K. Jones, S. Conde-Ceide, H. M. Tong, J. M. Bartolome-Nebreda and G. J. Macdonald, World Patent WO2012078817A1, Vanderbilt University, USA, 2012.

4 R. Apodaca, J. G. Breitenbucher, N. A. Hawryluk, W. M. Jones, J. M. Keith, J. E. Merit, M. S. Tichenor and A. K. Timmons, World Patent WO2008153752A2, Janssen Pharmaceutica N.V., Belg. Netherland, 2008.

5 C. F. Bigge, S. X. Cai, E. Weber, R. Woodward, N. C. Lan, J. F. W. Keana, Z.-L. Zhou and J. Wright, World Patent WO9723214A1, Warner-Lambert Company, CoCensys, Inc., USA, 1997.

6 G. Csjernyik, S. Karlstrom, A. Kers, K. Kolmodin, M. Nylof, L. Ohberg, L. Rakos, L. Sandberg, F. Sehgelmeble, P. Soderman, B. M. Swahn and S. Von Berg, World Patent WO 2012/087237A1, A. B. Astrazeneca, 2012.

7 A. Daina, C. Giuliano, C. Pietra, J. Wang, Y. Chi, Z. Zou, F. Li, Z. Yan, Y. Zhou, A. Guainazzi, S. Garcia Rubio and V. Zoete, J. Med. Chem., 2018, 61, 11039-11060.

8 C. Giuliano, S. G. Rubio, A. Daina, A. Guainazzi and C. Pietra, World Patent WO2015/134839 A1, Helsinn Healthcare SA, Switzerland, 2015.

9 A. Fonari, J. C. Roeder, H. Shen, T. V. Timofeeva and K. P. C. Vollhardt, Synlett, 2014, 25, 2429-2433.

10 S. Reimann, P. Ehlers, M. Sharif, K. Wittler, A. Spannenberg, R. Ludwig and P. Langer, Catal. Commun., 2012, 25, 142-147.

11 J. Panteleev, L. Zhang and M. Lautens, Angew. Chem., Int. Ed., 2011, 50, 9089-9092.

12 K. Miki, H. Kuge, R. Umeda, M. Sonoda and Y. Tobe, Synth. Commun., 2011, 41, 1077-1087.

13 W. A. Carroll, D. M. Kalvin, A. Perez Medrano, A. S. Florjancic, Y. Wang, D. L. Donnelly-Roberts, M. T. Namovic, G. Grayson, P. Honore and M. F. Jarvis, Bioorg. Med. Chem. Lett., 2007, 17, 4044-4048.

14 D. L. Musso, M. J. Clarke, J. L. Kelley, G. E. Boswell and G. Chen, Org. Biomol. Chem., 2003, 1, 498-506.

15 K. Tsuneo, K. Hisatomo and K. Nobuo, World Patent WO2007JP50152, Seikagaku Kogyo Co Ltd, Japan, 2008.

16 V. M. Sviripa, W. Zhang, C. Liu and D. Watt, US Pat. 2015/ 272908, University of Kentucky Research Foundation, 
Pharmaceutical Sciences Faculty Patents USA, Lexington, KY, 2018.

17 J. Frackenpohl, T. Mueller, J. Dittgen, D. Schmutzler, J. P. Ruiz-Santaella Moreno and M. J. Hills, World Patent WO2014086751A1, Bayer CropScience AG, Germany, 2014.

18 G. P. Lahm and B. K. Smith, World Patent WO2012177668A1, E. I. du Pont de Nemours and Company, USA, 2012.

19 R. M. Al-Zoubi, W. K. Al-Jammal, M. Y. El-Khateeb and R. McDonald, Eur. J. Org. Chem., 2015, 3374-3384.

20 R. M. Al-Zoubi, H. Al-Mughaid, M. A. Al-Zoubi, K. T. Jaradat and R. McDonald, Eur. J. Org. Chem., 2015, 5501-5508.

21 R. M. Al-Zoubi, H. Al-Mughaid and R. McDonald, Aust. J. Chem., 2015, 68, 912-918.

22 R. M. Al-Zoubi, H. A. Futouh and R. McDonald, Aust. J. Chem., 2013, 66, 1570-1575.

23 N. N. Pham, G. A. Salman, M. B. Ponce, T. T. Dang, A. Spannenberg, P. Ehlers and P. Langer, Eur. J. Org. Chem., 2017, 3865-3873.

24 R. Balderrama-Martinez-Sotomayor, M. Flores-Jarillo and A. Alvarez-Hernandez, ARKIVOC, 2016, 36-47.

25 T. Usuki, H. Yamada, T. Hayashi, H. Yanuma, Y. Koseki, N. Suzuki, Y. Masuyama and Y. Y. Lin, Chem. Commun., 2012, 48, 3233-3235.

26 H. Yamada, T. Hayashi and T. Usuki, Bull. Chem. Soc. Jpn., 2015, 88, 673-683.

27 P. Ehlers, T. T. Dang, T. Patonay, A. Villinger and P. Langer, Eur. J. Org. Chem., 2013, 2000-2007.

28 I. Malik, Z. Ahmad, S. Reimann, M. Nawaz, T. Patonay and P. Langer, Synlett, 2012, 23, 1463-1466.

29 K. C. Majumdar and S. Nath, Synthesis, 2011, 1413-1418.

30 N. Ibrahim, F. Chevot and M. Legraverend, Tetrahedron Lett., 2011, 52, 305-307.

31 A. El Akkaoui, I. Bassoude, J. Koubachi, S. Berteina-Raboin, A. Mouaddib and G. Guillaumet, Tetrahedron, 2011, 67, 7128-7138.
32 D. Thibeault, M. Auger and J.-F. Morin, Eur. J. Org. Chem., 2010, 3049-3067.

33 CCDC-1982244-1982247 contain the supplementary crystallographic data for compounds $35_{\mathbf{A}}, \mathbf{6}_{\mathbf{A}}, \mathbf{2 3}_{\mathbf{A}}$ and $2 \mathbf{0}_{\mathbf{A}}$ respectively.

34 I. J. S. Fairlamb, C. T. O'Brien, Z. Lin and K. C. Lam, Org. Biomol. Chem., 2006, 4, 1213-1216.

35 R. Chinchilla and C. Najera, Chem. Soc. Rev., 2011, 40, 50845121.

36 L. Dokladalova, F. Bures, W. Kuznik, I. V. Kityk, A. Wojciechowski, T. Mikysek, N. Almonasy, M. Ramaiyan, Z. Padelkova, J. Kulhanek and M. Ludwig, Org. Biomol. Chem., 2014, 12, 5517-5527.

37 P. Ehlers, A. Petrosyan, A. Neubauer, T. Broese, S. Lochbrunner, T. V. Ghochikyan, A. S. Saghyan and P. Langer, Org. Biomol. Chem., 2014, 12, 8627-8640.

38 A. R. Kapdi and D. Prajapati, $R S C A d v$. , 2014, 4, 41245-41259. 39 A. K. Danodia, R. K. Saunthwal, M. Patel, R. K. Tiwari and A. K. Verma, Org. Biomol. Chem., 2016, 14, 6487-6496.

40 N. Park, K. C. Ko, H.-W. Shin, S. M. Lee, H. J. Kim, J. Y. Lee and S. U. Son, J. Mater. Chem. A, 2016, 4, 8010-8014.

41 P. O. Delaye, M. Penichon, H. Allouchi, C. EnguehardGueiffier and A. Gueiffier, Org. Biomol. Chem., 2017, 15, 4199-4204.

42 M. Yamaguchi and K. Manabe, Org. Biomol. Chem., 2017, 15, 6645-6655.

43 K. M. Saini, R. K. Saunthwal and A. K. Verma, Org. Biomol. Chem., 2017, 15, 10289-10298.

44 Y. Sasai, H. Tsuchida, T. Kakuta, T. Ogoshi and Y. Morisaki, Mater. Chem. Front., 2018, 2, 791-795.

45 O. S. Miljanic, K. P. C. Vollhardt and G. D. Whitener, Synlett, 2003, 29-34.

46 G. Mao, A. Orita, D. Matsuo, T. Hirate, T. Iwanaga, S. Toyota and J. Otera, Tetrahedron Lett., 2009, 50, 2860-2864. 